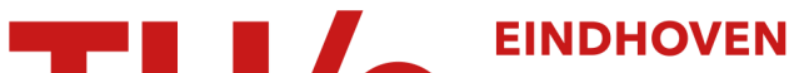 \\ UNIVERSITY OF \\ TECHNOLOGY
}

\section{High-spin cation radicals of meta-para aniline oligomers}

Citation for published version (APA):

Wienk, M. M., \& Janssen, R. A. J. (1997). High-spin cation radicals of meta-para aniline oligomers. Journal of the American Chemical Society, 119(19), 4492-4501. https://doi.org/10.1021/ja963772x

DOI:

10.1021/ja963772x

Document status and date:

Published: 01/01/1997

\section{Document Version:}

Publisher's PDF, also known as Version of Record (includes final page, issue and volume numbers)

\section{Please check the document version of this publication:}

- A submitted manuscript is the version of the article upon submission and before peer-review. There can be important differences between the submitted version and the official published version of record. People interested in the research are advised to contact the author for the final version of the publication, or visit the $\mathrm{DOI}$ to the publisher's website.

- The final author version and the galley proof are versions of the publication after peer review.

- The final published version features the final layout of the paper including the volume, issue and page numbers.

Link to publication

\section{General rights}

Copyright and moral rights for the publications made accessible in the public portal are retained by the authors and/or other copyright owners and it is a condition of accessing publications that users recognise and abide by the legal requirements associated with these rights.

- Users may download and print one copy of any publication from the public portal for the purpose of private study or research.

- You may not further distribute the material or use it for any profit-making activity or commercial gain

- You may freely distribute the URL identifying the publication in the public portal.

If the publication is distributed under the terms of Article $25 \mathrm{fa}$ of the Dutch Copyright Act, indicated by the "Taverne" license above, please follow below link for the End User Agreement:

www.tue.nl/taverne

Take down policy

If you believe that this document breaches copyright please contact us at:

openaccess@tue.nl

providing details and we will investigate your claim. 


\title{
High-Spin Cation Radicals of Meta-Para Aniline Oligomers
}

\author{
M. M. Wienk and R. A. J. Janssen*
}

Contribution from the Laboratory of Organic Chemistry, Eindhoven University of Technology, P.O. Box 513, $5600 \mathrm{MB}$ Eindhoven, The Netherlands

Received October 30, $1996^{\otimes}$

\begin{abstract}
A series of linear and branched high-spin di- and tri(cation radical)s $\left(\mathbf{1}^{\mathbf{2 \cdot 2}+}, \mathbf{7}^{\mathbf{2} 2+}, \mathbf{3}^{\mathbf{3 \cdot 3}+}, \mathbf{4}^{\mathbf{3 \cdot 3}+}\right.$, and $\mathbf{9}^{\mathbf{3 \cdot 3}+}$ ) has been prepared by oxidation of the corresponding meta-para aniline oligomers. The oligo(cation radical)s are stable under ambient conditions. The formation and properties of the cation radicals has been studied in detail by cyclic voltammetry and UV-vis-near IR spectroscopy. ESR spectroscopy has provided the zero-field splittings, which are consistent with the topology of the molecules and the localization of the unpaired electrons. Variable temperature ESR measurements reveal that the signal intensity follows Curie's law, consistent with a low-energy high-spin state. The stability of the high-spin meta-para aniline oligomers and the possibility to extend these systems demonstrate that alternating meta and para aniline oligomers are promising building blocks for future polaronic ferromagnets.
\end{abstract}

\section{Introduction}

Intramolecular ferromagnetic interaction between the unpaired electrons of oligo- and polyradicals attracts considerable interest for the development of high-spin organic molecules and molecular ferromagnets. ${ }^{1}$ Taking advantage of the topology and in-phase periodicity of the spin polarization in alternant hydrocarbons, a large number of high-spin molecules have been prepared. Especially, connecting various open-shell centers via $m$-phenylene has resulted in several organic high-spin systems. ${ }^{2}$

A promising extension to this strategy is the concept of a polaronic ferromagnetic chain, based on an alternating sequence of dopable, $\pi$-conjugated segments and ferromagnetic spincoupling units. ${ }^{3}$ Oxidative or reductive doping of such a polymer may result in polaronic (radical ion) segments that are ferromagnetically coupled, yielding a high-spin polyradical, possibly leading to an organic magnetic material. A number of polymers has been prepared to test the feasibility of this concept. $^{4}$

The process of doping is well established for $\pi$-conjugated polymers, leading to conducting materials. At high doping levels, however, most conjugated polymers have a rather low spin density due to the formation of spinless bipolarons or $\pi$-dimers. ${ }^{5}$ One exception is the emeraldine salt of polyaniline in which polarons are favored over the bipolaronic structure, resulting in a conducting polymer with considerable spin density.

${ }^{\otimes}$ Abstract published in Advance ACS Abstracts, April 15, 1997.

(1) (a) Magnetic Molecular Materials; Gatteschi, D., Kahn, O., Miller, J. S., Palacio, F., Eds; Kluwer Academic Publishers: Dordrecht, The Netherlands, 1991. (b) Chemistry and Physics of Molecular Based Magnetic Materials. Molecular Crystals and Liquid Crystals; Iwamura, H., Miller. J. S., Eds.; Gordon and Breach Publishers: New York, 1993; Vol. 232, pp 1-360. (c) Rajca, A. Chem. Rev. 1994, 94, 871.

(2) (a) Matsuda, K.; Nakamura, N.; Inoue, K.; Koga, N.; Iwamura, H. Bull. Chem. Soc. Jpn. 1996, 69, 1483. (b) Nishide, H.; Kaneko, T.; Toriu, S.; Kuzimaki, Y.; Tsuchida, E. Bull. Chem. Soc. Jpn. 1996, 69, 499. (c) Rajca, A.; Rajca, S.; Desai, S. R. J. Am. Chem. Soc. 1995, 117, 806. (d) Jacobs, S. J.; Dougherty, D. A. Angew. Chem. 1994, 106, 1155.

(3) (a) Fukutome, H.; Takahashi, I.; Ozaki, M. Chem. Phys. Lett. 1987, 133, 34. (b) Kaisaki, D. A.; Chang, W.; Dougherty, D. A. J. Am. Chem. Soc. 1991, 113, 2764. (c) Tanaka, K.; Ago, H.; Yamabe, T. Synth. Met. 1995, 72, 225.

(4) (a) Murray, M. M.; Kaszynski, P.; Kaisaki, D. A.; Chang, W.; Dougherty, D. A. J. Am. Chem. Soc. 1994, 116, 8152. (b) Bushby, R. J.; Ng, K. M. Chem. Commun. 1996, 659.

(5) (a) Patil, A. O.; Heeger, A. J.; Wudl, F. Chem. Rev. 1988, 88, 183. (b) Brédas, J. L.; Street, G. B. Acc. Chem. Res. 1985, 18, 309. (c) Hill, M. G.; Mann, K. R.; Miller, L. L.; Penneau, J.-P. J. Am. Chem. Soc. 1992, 114, 2728.
The repeat unit of the emeraldine salt comprises one polaron, effectively stabilized by delocalization of the unpaired electron and charge within two aniline units. ${ }^{6}$ Whereas coupling of such a $N$-phenyl- $p$-phenylenediamine repeat unit via the para positions leads to a conducting polymer, coupling via the meta positions is expected to lead to a high-spin polymer.
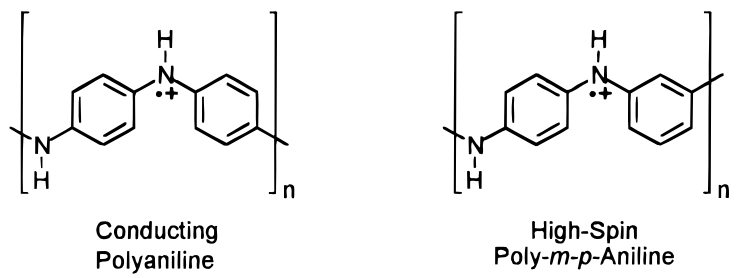

High-Spin
Poly-m-p-Aniline

The proposed poly meta-para aniline comprises alternating meta- and para-linked aniline units, which upon doping give rise to ferromagnetic spin alignment from the $m$-phenylenediamine units and to the desired chemical stability from the $p$-phenylenediamine units. Recently, we have demonstrated the viability of this concept by the preparation of the triplet groundstate di(cation radical) of a $N$-phenyl-substituted meta-para aniline oligomer (1), which is stable at room temperature. ${ }^{7}$ Although several other high-spin molecules based on nitrogen cation radicals and $m$-phenylene have been reported, these systems suffered from irreproducability, ${ }^{8}$ poor stability, ${ }^{9}$ or they cannot easily be extended to larger systems. ${ }^{10}$ In addition, we have demonstrated that proton-induced spin unpairing can be used to prepare a high-spin di(cation radical) aniline oligomer from the combination of a fully reduced meta-para aniline oligomer (7) and the corresponding fully oxidized imine

(6) (a) Wudl, F.; Angus, R. O.; Lu, F. L.; Allemand, P. M.; Vachon, D. J.; Nowak, M.; Liu, Z. X.; Heeger, A. J. J. Am. Chem. Soc. 1987, 109, 3677. (b) Stafström, S.; Brédas, J. L.; Epstein, A. J.; Woo, H. S.; Tanner, D. B.; Huang, W. S.; MacDiarmid, A. G. Phys. Rev. Lett. 1987, 59, 1464

(7) Wienk, M. M.; Janssen, R. A. J. Chem. Commun. 1996, 268.

(8) Torrance, J. B.; Oostra, S.; Nazzal, A. Synth. Met. 1987, 19, 709.

(9) (a) Stickley, K. R.; Blackstock, S. C. J. Am. Chem. Soc. 1994, 116, 11576. (b) Sasaki, S.; Iyoda, M. Chem. Lett. 1995, 1011. (c) Yoshizawa, K.; Tanaka, K.; Yamabe, T.; Yamauchi, J. J. Chem. Phys. 1992, 96, 5516. (d) Yoshizawa, K.; Hatanak, M.; Ago, H.; Tanaka, K.; Yamabe, T, Bull. Chem. Soc. Jpn. 1996, 69, 1417. (e) Ito, A.; Saito, T.; Tanaka, K.; Yamabe, T. Tetrahedron Lett. 1995, 48, 8890.

(10) (a) Nakamura, Y.; Iwamura, H. Bull. Chem. Soc. Jpn. 1993, 66, 3724. (b) Okada, K.; Imakura, T.; Oda, M.; Murai, H.; Baumgarten, M. J. Am. Chem. Soc. 1996, 118, 3047. 


\section{Scheme $1^{a}$}

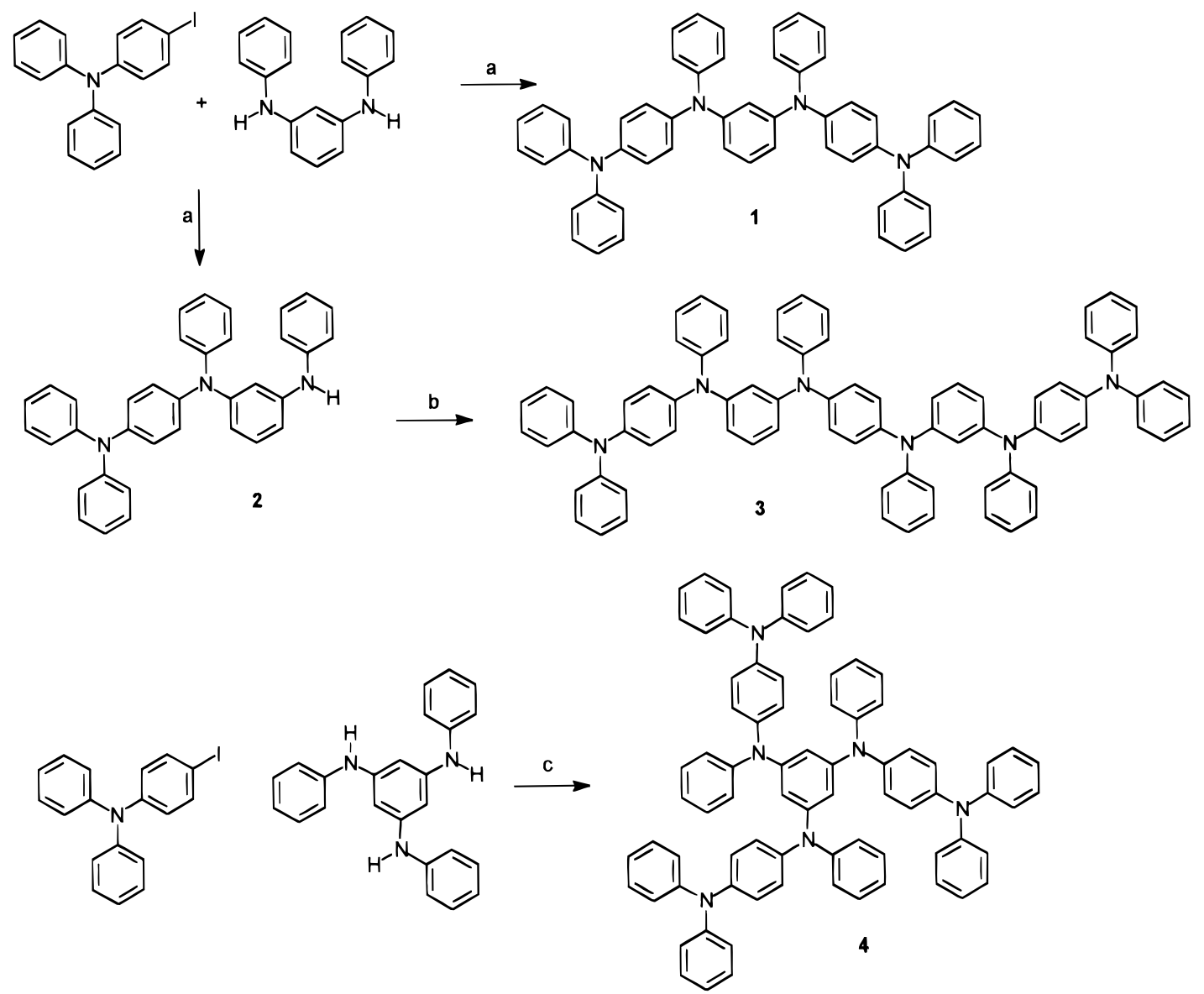

\footnotetext{
${ }^{a}$ Reaction conditions: (a) $n$-BuLi, $\mathrm{CuI}, \mathrm{Ph}_{2} \mathrm{O}, 200{ }^{\circ} \mathrm{C}, 48 \mathrm{~h}$; (b) 1,4-diiodobenzene, $\mathrm{NaH}, \mathrm{CuI}, \mathrm{Ph}_{2} \mathrm{O}, 200{ }^{\circ} \mathrm{C}, 48 \mathrm{~h} ;(\mathrm{c}) \mathrm{NaH}, \mathrm{CuI}, \mathrm{Ph} 2 \mathrm{O}, 200{ }^{\circ} \mathrm{C}$,
} $48 \mathrm{~h}$.

oligomer $(\mathbf{8}) .{ }^{11}$ This process is similar to the acid doping of the emeraldine base of polyaniline. ${ }^{12}$

In this paper, we present a detailed investigation of the redox, optical, and magnetic properties of the triplet state di(cation radical)s $\mathbf{1}^{\mathbf{2 \cdot 2}+}$ and $\mathbf{7}^{\mathbf{2 \cdot 2}+}$. Furthermore, we show that it is possible to extend the intramolecular ferromagnetic spin-spin interaction in one and two dimensions by the preparation of linear and branched meta-para aniline oligomers $(\mathbf{3}, 4$, and 9). Oxidation of these precursors to an intermediate oxidation state, in which one electron is removed from each $p$-phenylenediamine unit, results in ground state high-spin molecules with a remarkable chemical stability. The intermediate oxidation state can be reached by chemical oxidation or by a convenient proton-triggered redox reaction for the secondary amines 7 and 9. The chemical stability and high-spin properties of the cation radicals of the meta-para aniline oligomers confirm that the meta-para aniline concept is a promising approach to highspin polyradicals. Moreover, the present study demonstrates that the ferromagnetic spin alignment can successfully be extended, both in one and two dimensions.

\section{Results and Discussion}

Synthesis. Tetraamine 1 was synthesized from $N, N^{\prime}$-diphenyl-1,3-benzenediamine and 2 equiv of 4-iodo- $N, N$-diphenylaniline in diphenyl ether at $200{ }^{\circ} \mathrm{C}$, using $n$-butyllithium and copper(I) iodide as a catalyst (Scheme 1). The product was

(11) Wienk, M. M.; Janssen, R. A. J. J. Am Chem. Soc. 1996, 118, 10626.

(12) (a) Huang, W.-S.; Humphrey, B. D.; MacDiarmid, A. G. J. Chem. Soc., Faraday Trans. 1 1986, 82, 2385. (b) MacDiarmid, A. G.; Epstein, A. J. Faraday Discuss. Chem. Soc. 1989, 88, 317. isolated by flash column chromatography and recrystallization from benzene. When only 1 equiv of 4 -iodo- $N, N$-diphenylaniline was used, a mixture of $\mathbf{1}$ and the singly coupled product $\mathbf{2}$, as well as some unreacted $N, N^{\prime}$-diphenyl-1,3-benzenediamine was obtained. These were separated by flash column chromatography. Reaction of 2 with 0.5 equiv of 1,4-diiodobenzene afforded hexaamine 3 . Star-shaped hexaamine 4 was synthesized from $N, N^{\prime}, N^{\prime \prime}$-triphenyl-1,3,5-benzenetriamine and 3 equiv of 4-iodo- $N, N$-diphenylaniline.

Tetraamine 7 was synthesized starting from $N$-phenyl-1,4benzenediamine. Diacetylation with acetic anhydride in acetic acid gave compound $\mathbf{5}$, and coupling with 1,3-dibromobenzene, using potassium carbonate and copper(I) iodide as catalyst, afforded tetraamide 6. Finally, hydrolysis with sodium hydroxide in water/ethanol lead to compound 7 (Scheme 2). Oxidation of $\mathbf{7}$ with lead(IV) oxide in chloroform gave tetraimine $\mathbf{8}$ as a mixture of three cis-trans isomers. These isomers could not be separated since isomerization takes place during column chromatography. Hexaamine 9 was prepared by an iodinecatalyzed condensation reaction between phloroglucinol and $\mathrm{N}$-phenyl-1,4-benzenediamine. Oxidation to the hexaimine $\mathbf{1 0}$ with lead(IV) oxide was carried out in dioxane.

Cyclic Voltammetry. Electrochemical studies on $N$-phenylsubstituted oligomers $\mathbf{1}, \mathbf{3}$, and $\mathbf{4}$ were carried out in dichloromethane with $0.1 \mathrm{M}$ tetrabutylammonium hexafluorophosphate (TBAH) as supporting electrolyte. The results are summarized in Table 1.

The cyclic voltammogram of $\mathbf{1}$ reveals four consecutive oneelectron oxidation waves (Figure 1). The anodic and cathodic waves are separated by $62-65 \mathrm{mV}$, independent of the scan 
Scheme $2^{a}$

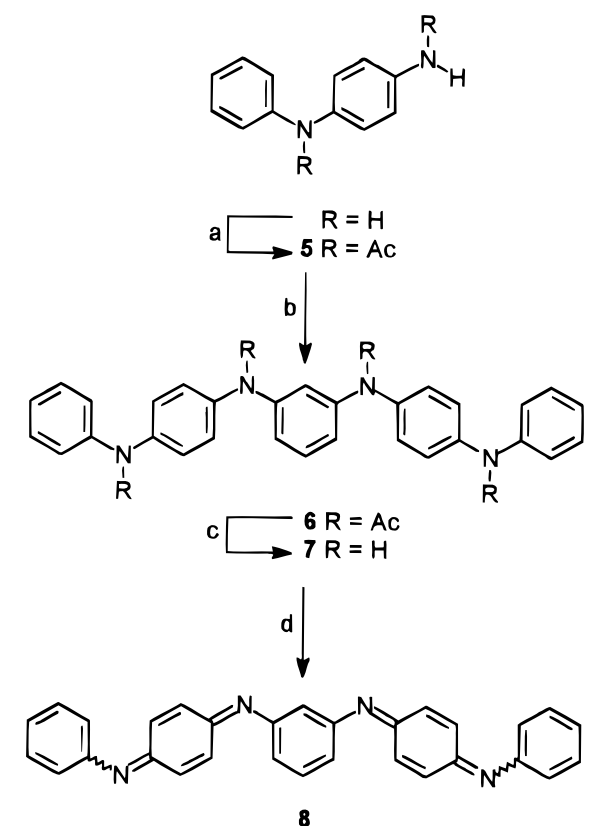

3<smiles>Nc1ccc(Nc2ccccc2)cc1</smiles><smiles>c1ccc(Nc2ccc(Nc3cc(Nc4ccc(Nc5ccccc5)cc4)cc(Nc4ccc(Nc5ccccc5)cc4)c3)cc2)cc1</smiles>

9

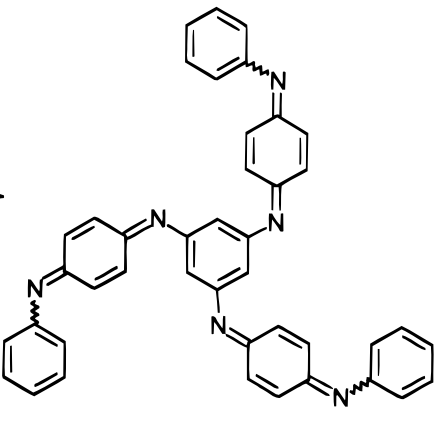

10

${ }^{a}$ Reaction conditions: (a) $\mathrm{Ac}_{2} \mathrm{O}, \mathrm{AcOH}, 70{ }^{\circ} \mathrm{C}, 2 \mathrm{~h}$; (b) 1,3-dibromobenzene, $\mathrm{K}_{2} \mathrm{CO}_{3}$, CuI, ethoxyethyl ether, $200{ }^{\circ} \mathrm{C}, 24 \mathrm{~h}$; (c) $\mathrm{NaOH}$; EtOH/ $\mathrm{H}_{2} \mathrm{O}, 78{ }^{\circ} \mathrm{C}, 48 \mathrm{~h}$; (d) $\mathrm{PbO}_{2}, \mathrm{CHCl}_{3}, \mathrm{rt}, 15 \mathrm{~min}$; (e) $\mathrm{I}_{2}, 180{ }^{\circ} \mathrm{C}, 6 \mathrm{~h}$; (f) $\mathrm{PbO}_{2}$, dioxane, $30 \mathrm{~min}$.

Table 1. Redox Potentials of Oligomers vs SCE

\begin{tabular}{ccccccc}
\hline & $E^{0}{ }_{1}(\mathrm{~V})$ & $E^{0}{ }_{2}(\mathrm{~V})$ & $E^{0}{ }_{3}(\mathrm{~V})$ & $E^{0}{ }_{4}(\mathrm{~V})$ & $E^{0}{ }_{5}(\mathrm{~V})$ & $E^{0}{ }_{6}(\mathrm{~V})$ \\
\hline $\mathbf{1}^{a}$ & 0.54 & 0.68 & & 1.13 & 1.22 & \\
$\mathbf{3}^{a}$ & $0.56^{c}$ & $0.56^{c}$ & 0.75 & $1.14^{c}$ & $1.14^{c}$ & 1.29 \\
$\mathbf{4}^{a}$ & 0.52 & 0.66 & 0.74 & 1.16 & 1.29 & 1.34 \\
$\mathbf{7}^{b}$ & $0.63^{c}$ & $0.63^{c}$ & & $0.89^{c}$ & $0.89^{c}$ & \\
$\mathbf{9}^{b}$ & $0.66^{c}$ & $0.66^{c}$ & $0.66^{c}$ & $0.88^{c}$ & $0.88^{c}$ & $0.88^{c}$ \\
\hline
\end{tabular}

${ }^{a}$ Cell is calibrated against $\mathrm{Fc} / \mathrm{Fc}^{+}(0.47 \mathrm{~V}) .{ }^{b}$ Cell is calibrated against $\mathrm{Fc} / \mathrm{Fc}^{+}(0.43 \mathrm{~V}) .{ }^{c}$ Peaks are unresolved.

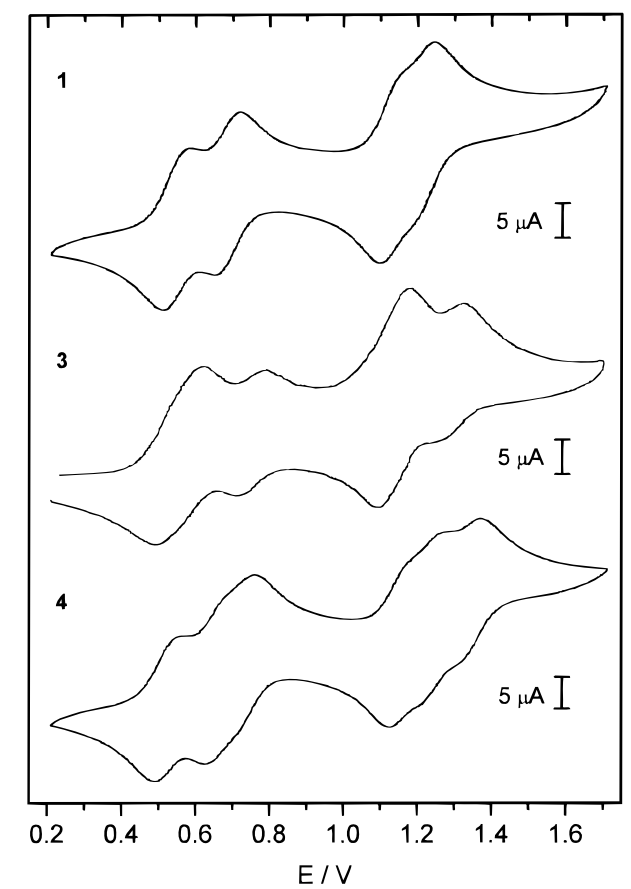

Figure 1. Cyclic voltammogram of $N$-phenyl aniline oligomers 1, 3, and 4 in $\mathrm{CH}_{2} \mathrm{Cl}_{2} / \mathrm{Bu}_{4} \mathrm{~N}^{+} \mathrm{PF}_{6}^{-}(0.1 \mathrm{M})$ at $295 \mathrm{~K}$, scan rate $100 \mathrm{mV} / \mathrm{s}$, potential vs SCE calibrated against $\mathrm{Fc} / \mathrm{Fc}^{+}(0.47 \mathrm{~V})$.

rate between 50 and $200 \mathrm{mV} / \mathrm{s}$. These measurements demonstrate that, at room temperature, oxidation of $\mathbf{1}$ is a chemically reversible process, in which up to four electrons can be removed, illustrating the stability of the generated cation radicals. The first two waves that occur at a potential of ca. $0.6 \mathrm{~V}$ are due to the removal of one electron from each of the two $p$-phenylenediamine moieties present in the molecule. At a potential of ca. $1.1 \mathrm{~V}$, both units are oxidized for a second time, giving rise to a third and fourth wave. Comparison with the oxidation potentials for the corresponding all-para-substituted isomer $(0.42,0.68,1.15 \text {, and } 1.31 \mathrm{~V})^{13}$ reveals that $E^{0}{ }_{2}$ and $E^{0}{ }_{3}$ are identical, whereas $E^{0}{ }_{1}$ and $E^{0}{ }_{4}$ of $\mathbf{1}$ are higher and lower, respectively. The decreased separation between $E^{0}{ }_{1}$ and $E_{2}^{0}$, as well as between $E_{3}^{0}$ and $E^{0}{ }_{4}$, is consistent with the nonresonant nature of the central $m$-phenylene unit.

The cyclic voltammogram of $\mathbf{3}$ also reveals four reversible redox waves, but the currents associated with the first and third wave are almost twice as large as those for the second and the fourth wave (Figure 1). Hence, the first and third waves correspond to two-electron oxidations, while the second and third waves are one-electron oxidations. The peak-to-peak separations of the first and third wave (ca. 120 and $90 \mathrm{mV}$ ) are significantly larger than the theoretical value of $59 \mathrm{mV}$, while the second and fourth waves have peak-to-peak separations of 65 and $68 \mathrm{mV}$, respectively. This behavior can be rationalized assuming that electrostatic repulsion favors the localization of the first two charges in the two outer $p$-phenylenediamine units. In this view, the third oxidation wave corresponds to removing an electron from the central unit and occurs at significantly higher potential as a result of the charges in the two adjacent units. Similar effects occur at higher potential, when a second electron is removed from each unit.

In the cyclic voltammogram of $\mathbf{4}$ (Figure 1), six reversible oxidation waves of equal magnitude can be distinguished. Some of these transitions only show up as shoulders, and it is not possible to determine the peak-to-peak separation accurately. However, for all six waves it is close to the theoretical value of $59 \mathrm{mV}$. In contrast to the linear hexamer 3, the star-shaped isomer 4 contains three equivalent $p$-phenylenediamine units.

(13) Strohriegl, P.; Jesberger, G.; Heinze, J.; Moll, T. Makromol. Chem. 1992, 193, 909. The reported values have been scaled by $+0.12 \mathrm{~V}$ to correct for the difference in $E_{0}$ of the $\mathrm{Fc} / \mathrm{Fc}^{+}$couple, due to different experimental conditions. 


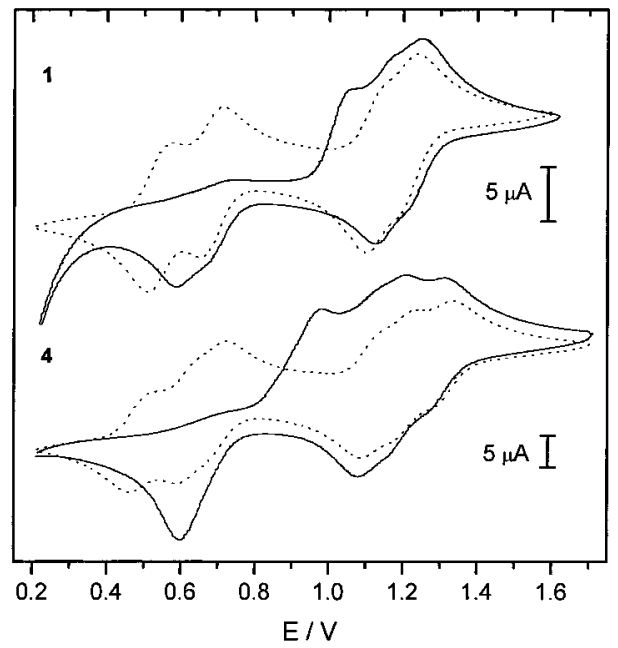

Figure 2. Cyclic voltammogram of $N$-phenyl aniline oligomers 1 and 4 in $\mathrm{CH}_{2} \mathrm{Cl}_{2} / \mathrm{Bu}_{4} \mathrm{~N}^{+} \mathrm{PF}_{6}{ }^{-}(0.1 \mathrm{M})$ at $295 \mathrm{~K}$, scan rate $100 \mathrm{mV} / \mathrm{s}$, potential vs SCE calibrated against $\mathrm{Fc} / \mathrm{Fc}^{+}(0.45 \mathrm{~V})$ : $(\cdots)$ without TFA; $(-)$ with $4 \%$ (v/v) TFA.

As a consequence, the charges in the dication cannot keep away from each other and six separate oxidation/reduction waves are observed.

Since exploratory experiments ${ }^{7}$ showed that the presence of a trace of a Brønsted acid has a very pronounced effect on the ESR spectra of the oxidized oligomers, we investigated the influence of acid on the redox properties. The addition of small portions of trifluoroacetic acid (TFA) to the electrolyte solution has a distinct effect on the voltammograms of the $N$-phenyl aniline oligomers $\mathbf{1}, \mathbf{3}$, and $\mathbf{4}$. The first set of oxidation waves shifts $0.4-0.5 \mathrm{~V}$ to higher potential, whereas the reduction waves remain at the same position (Figure 2). Remarkably, this effect occurs much more rapidly for the star-shaped hexaamine 4. With only $0.1 \%(\mathrm{v} / \mathrm{v})$ of TFA, the oxidation waves of $\mathbf{4}$ start shifting, whereas 10 times more acid is needed to cause the same effect for compounds $\mathbf{1}$ and $\mathbf{3}$.

The increase of the first oxidation potentials in the presence of TFA can be rationalized by the protonation of the $p$ phenylenediamine units at one of the nitrogen atoms. Since protonated amines carry a positive charge, withdrawal of an electron will be more difficult. Acid has no effect on the position of the second set of oxidation waves in the investigated acidity range, suggesting that deprotonation occurs, as soon as a protonated $p$-phenylenediamine unit is oxidized. The fact that the reduction waves are not influenced by the acid is in full agreement with this explanation. Remarkably, the threshold for the acid-induced shift of the first oxidation waves is much lower for compound $\mathbf{4}$ than for the linear compounds $\mathbf{1}$ and $\mathbf{3}$. Furthermore, on $N, N, N^{\prime}, N^{\prime}$-tetraphenyl-1,4-benzenediamine (TPBD), lacking a 1,3-benzenediamine unit, addition of acid has no effect at all. ${ }^{14}$ These differences are tentatively ascribed to a stabilization of the protonated 1,3-benzenediamine and 1,3,5-benzenetriamine rings via tautomeric intermediates such as depicted below.

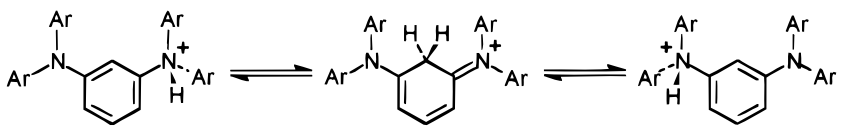

Cyclic voltammetry of compounds $\mathbf{7}$ and $\mathbf{9}$ was carried out in acetonitrile with $0.1 \mathrm{M} \mathrm{TBAH}$ and in the presence of 0.01 $\mathrm{M}$ perchloric acid, since it is well-known that the removal of

(14) Durand, G.; Morin, G.; Trémillon, B. Nouv. J. Chim. 1979, 7, 463.

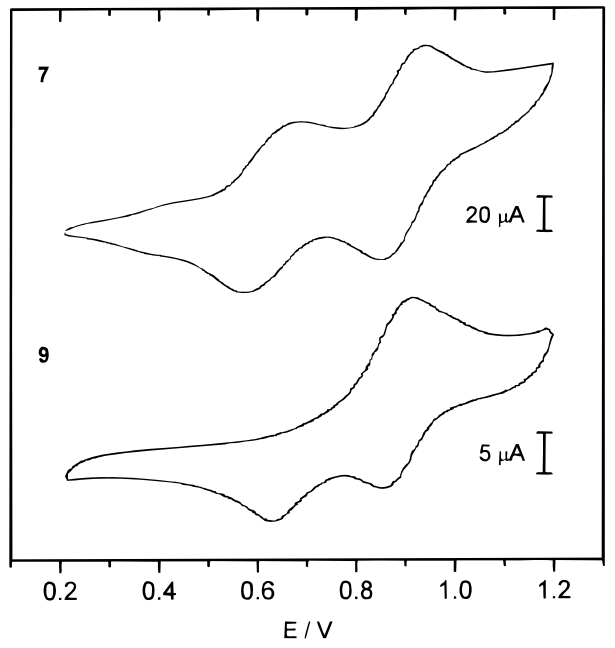

Figure 3. Cyclic voltammogram of unsubstituted aniline oligomers 7 and 9 in $\mathrm{CH}_{2} \mathrm{Cl}_{2} / \mathrm{Bu}_{4} \mathrm{~N}^{+} \mathrm{PF}_{6}^{-}(0.1 \mathrm{M}) / \mathrm{HClO}_{4}(0.01 \mathrm{M})$ at $295 \mathrm{~K}$, scan rate $100 \mathrm{mV} / \mathrm{s}$, potential vs $\mathrm{SCE}$ calibrated against $\mathrm{Fc} / \mathrm{Fc}^{+}(0.43 \mathrm{~V})$.

two electrons from a $p$-phenylenediamine unit with secondary amines leads to deprotonation and irreversible oxidation processes. ${ }^{15}$ In the presence of acid, deprotonation is suppressed and the voltammogram of tetraamine 7 reveals two broad reversible oxidations (Figure 3). The peak-to-peak separations of 95 and $81 \mathrm{mV}$ are significantly larger than $59 \mathrm{mV}$. From the rather large peak-to-peak separation between the oxidation waves observed for compound $\mathbf{7}$ and comparison with the values reported for $N, N^{\prime}$-diphenyl-1,4-benzenediamine (DPBD), we conclude that these waves represent two-electron processes. Apparently, both $p$-phenylenediamine moieties are oxidized simultaneously under these conditions.

Hexaamine 9 is measured at lower concentration because otherwise the voltammogram only reveals very broad uninformative oxidation/reduction waves. At lower concentration, only one oxidation wave is observed, at a potential comparable to the second oxidation wave of 7 (Figure 3). During the reversing scan, two waves are detected, but their currents are smaller than the current of the oxidation wave. Identical behavior is observed for successive scans. Since the oxidation wave is twice as large as either one of the reduction waves, we assume that the first wave, which is associated with the simultaneous oxidation of all three $p$-phenylendiamine units, is overlapping the second wave. Similar to the behavior of the $N$-phenyl-substituted oligomers, the shift is the result of protonation.

UV-Vis-Near IR Measurements. Quantitative conversion of the amines to the different oxidation states has been achieved by chemical oxidation with either thianthrenium perchlorate $\left(\mathrm{Thi}^{+} \mathrm{ClO}_{4}^{-}\right)^{16}$ or phenyliodine(III) bis(trifluoroacetate) (PIFA) ${ }^{17}$ in dichloromethane or acetonitrile. The reaction was monitored by UV-vis-near IR spectroscopy (Table 2).

The absorption spectrum of neutral $\mathbf{1}$ in dichloromethane has a maximum at $3.93 \mathrm{eV}$ and does not differ much from the absorption spectrum of TPBD. Apparently, the addition of a second $p$-phenylenediamine unit at the meta position of one of the outer phenyl rings does not influence the effective conjugation length significantly. Upon stepwise addition of small portions of $\mathrm{Thi}^{+} \mathrm{ClO}_{4}{ }^{-}$, the absorption of neutral amine decreases, and new bands appear at 1.44 and $3.02 \mathrm{eV}$ with an

(15) (a) Wolf, J. F.; Forbes, C. E.; Gould, S.; Shacklette, L. W. J. Electrochem. Soc. 1989, 136, 2887. (b) Moll, T.; Heinze, J. Synth. Met. 1993, 55-57, 1521.

(16) Murata, Y.; Shine, H. J. J. Org. Chem. 1969, 34, 3368.

(17) Eberson, L.; Hartshorn, M. P.; Persson, O. Acta Chem. Scand. 1995, 49,640 . 
Table 2. Spectral Data for the Amine Oligomers and Corresponding Cation Radicals

\begin{tabular}{lllc}
\hline & \multicolumn{1}{c}{ neutral, eV (nm) } & \multicolumn{1}{c}{$\begin{array}{c}\text { intermediate } \\
\text { oxidation state, } \\
\mathrm{eV}(\mathrm{nm})\end{array}$} & $\begin{array}{c}\text { fully } \\
\text { oxidized state, } \\
\mathrm{eV}(\mathrm{nm})\end{array}$ \\
\hline $\mathrm{TPBD}^{a}$ & $3.97(312)$ & $1.44(861) ; 3.05(407)$ & $2.09(593)$ \\
$\mathbf{1}^{a}$ & $3.93(316)$ & $1.44(861) ; 3.02(411)$ & $2.10(590)$ \\
$\mathbf{3}^{a}$ & $4.01(309)$ & $1.44(861) ; 3.07(404)$ & $2.11(588)$ \\
$\mathbf{4}^{a}$ & $3.93(316)$ & $1.34(925) ; 2.97(418)$ & $2.08(596)$ \\
$\mathrm{DPDB}^{b}$ & $4.08(304)$ & $1.78(697) ; 3.25(381)$ & $2.30(539)$ \\
$\mathbf{7}^{b}$ & $4.05(306)$ & $1.67(743) ; 3.17(391)$ & $2.31(537)$ \\
$\mathbf{8}^{b}$ & $2.74(452) ; 4.05(306)$ & & \\
$\mathbf{9}^{b}$ & $4.01(309)$ & $1.67(743) ; 3.13(396)$ & $2.33(533)$ \\
$\mathbf{1 0}^{b}$ & $2.72(456) ; 4.01(309)$ & & \\
\hline
\end{tabular}

${ }^{a}$ Recorded in dichloromethane. ${ }^{b}$ Recorded in $\mathrm{CH}_{2} \mathrm{Cl}_{2} / \mathrm{TFA}(9: 1 \mathrm{v} / \mathrm{v})$.

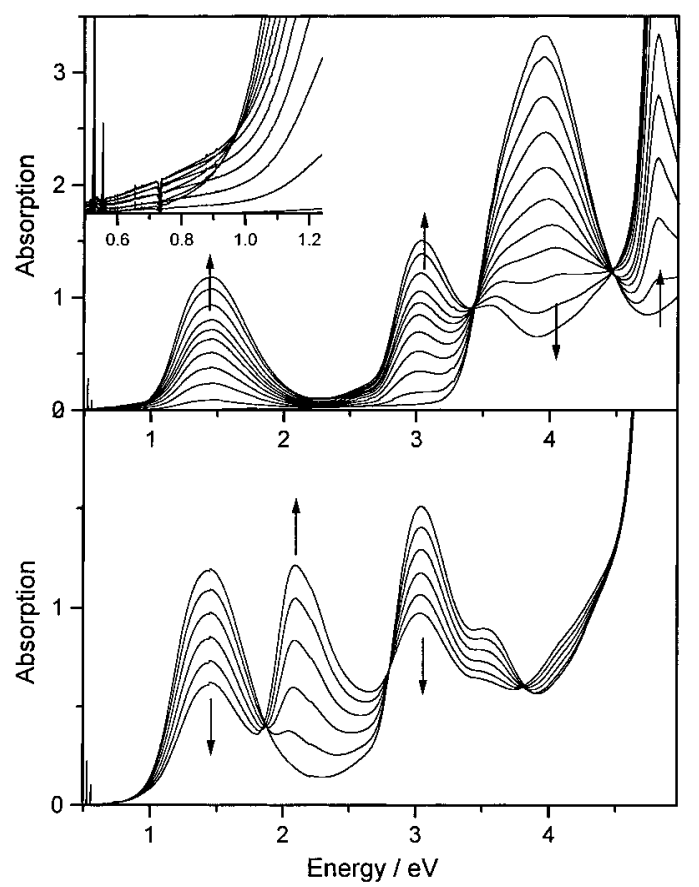

Figure 4. UV-vis-near IR spectra of the stepwise oxidation of $\mathbf{1}$ with $\mathrm{Thi}^{+} \mathrm{ClO}_{4}{ }^{-}$in $\mathrm{CH}_{2} \mathrm{Cl}_{2}$ at $295 \mathrm{~K}$ : (top) oxidation of $\mathbf{1}$ to $\mathbf{1}^{\mathbf{}}$ to $\mathbf{1}^{\mathbf{2 0 2}+}$ (inset shows enlarged near IR region); (bottom) oxidation from $\mathbf{1}^{\mathbf{2 0 2}+}$ to $\mathbf{1}^{\mathbf{3 \cdot 3}+}$. The band at $4.80 \mathrm{eV}$ is caused by neutral thianthrene.

isosbestic point at $3.42 \mathrm{eV}$ (Figure 4). The new absorption bands have a close resemblance to the bands of singly oxidized TPBD. When 1 equiv of oxidant is added, the band at $3.93 \mathrm{eV}$ has decreased to half of the original intensity. On the basis of the difference between the oxidation potentials for the removal of the first and the second electron, one can expect that no significant disproportionation will occur, and most molecules will be singly oxidized to the mono(cation radical) $\mathbf{1}^{\bullet+}$. Apparently, the optical spectrum of $\mathbf{1}^{\bullet+}$ can be described with a superposition of the absorption bands of neutral and singly oxidized $p$-phenylenediamine units. After 2 equiv was added, the absorption at $3.93 \mathrm{eV}$ disappeared completely and the bands at 1.44 and $3.02 \mathrm{eV}$ reached maximum intensity. This demonstrates that in the di(cation radical) $\mathbf{1}^{\mathbf{2 . 2}+}$ one electron is removed from each $p$-phenylenediamine unit. Further oxidation leads to a constant decrease in the bands at 1.44 and $3.04 \mathrm{eV}$, which are replaced by a new band at $2.09 \mathrm{eV}$. During this process, two isosbestic points are observed at 1.86 and 3.81 $\mathrm{eV}$. The absorption at $2.09 \mathrm{eV}$ is similar to the absorption band of doubly oxidized TPBD, indicating that a second electron is removed out each $p$-phenylenediamine unit. When finally an excess of a reducing agent, like hydrazine monohydrate, is added

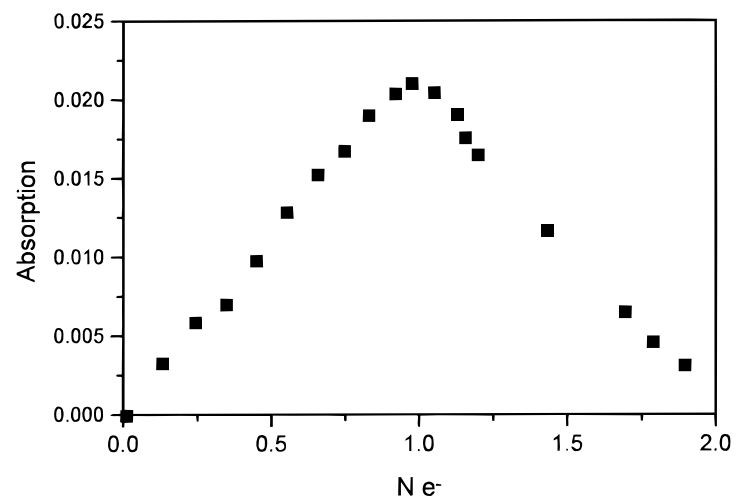

Figure 5. Evolution of the intensity of the intervalence band of $\mathbf{1}^{\boldsymbol{}^{+}}$as a function of the average number of electrons removed.

to the fully oxidized aniline oligomer, the initial spectrum of $\mathbf{1}$ is recovered, demonstrating the reversibility of the oxidation process.

Careful analysis of the near IR region of the spectrum of $\mathbf{1}^{\mathbf{+}}$ reveals a very weak band around $0.9 \mathrm{eV}$ which reaches a maximum after addition of 1 equiv of oxidizing agent. Since this band is not only very weak but also very broad and partially overlapped by the much stronger band at $1.44 \mathrm{eV}$, the energy of the absorption maximum cannot be determined accurately. The broad band has the characteristics of an intervalence transition. Since $\mathbf{1}^{\bullet+}$ is a mixed-valence compound, intramolecular electron transfer can occur, giving rise to an intervalence band. ${ }^{18}$ For this band, the evolution of the optical density as a function of the average number of removed electrons is expected to increase linearly, until one electron is removed. At that stage, $\mathbf{1}^{\bullet+}$ has reached maximum concentration, and upon further oxidation to $\mathbf{1}^{\mathbf{2 \cdot 2}+}$, the intensity of the intervalence band will decrease again. The observed behavior of the absorption at 0.9 $\mathrm{eV}$ is in excellent agreement with this prediction (Figure 5). An intervalence band of $\mathbf{1}^{\mathbf{3 \cdot 3}+}$, which is also a mixed-valence compound, however, is not observed in the region between 0.4 $\mathrm{eV}$ and the onset of the low-energy cation band. This may be due to a low intensity or the absorption may be obscured by another band.

Similar optical spectra, including intervalence bands, are recorded for the stepwise oxidation of the linear and star-shaped hexamers 3 and 4 (Table 2). The evolution of the intervalence bands of the mixed-valence species of $\mathbf{3}$ and $\mathbf{4}$ during the oxidation process is not as straightforward as for compound $\mathbf{1}$. Remarkably, the intensity of the intervalence band related to $\mathbf{4}^{\bullet+}$ and $\mathbf{4}^{\mathbf{2} \cdot \mathbf{3}+}$ already decreases, well before an average of one electron has been removed.

When PIFA is used as oxidizing agent in dichloromethane/ trifluoroacetic acid $(9: 1 \mathrm{v} / \mathrm{v})$ solution the reaction does not progress beyond the intermediate oxidation state, which is characterized by the bands at 1.4 and $3.0 \mathrm{eV}$, even when an excess of PIFA is added. So, this method is very convenient to obtain the intermediate oxidation states $\mathbf{1}^{\mathbf{2 \cdot 2}+}, \mathbf{3}^{\mathbf{3 \cdot 3}+}$, and $\mathbf{4}^{\mathbf{3 \cdot 3}+}$.

Chemical oxidation of the secondary amines $\mathbf{7}$ and $\mathbf{9}$ was carried out with $10 \%(\mathrm{v} / \mathrm{v})$ of TFA added to the solution in order to stabilize the generated cation radicals. In this acidic medium, the optical spectrum of 7 displays absorption bands at 3.31 and $4.27 \mathrm{eV}$, whereas the spectrum recorded in dichloromethane exhibits only one band at $4.05 \mathrm{eV}$. TFA causes a shift of the absorption to higher energy, probably because

(18) (a) Sedó, J.; Ruiz, D.; Vidal-Gancedo, J.; Rovira, C.; Bonvoisin, J.; Launay, J.-P.; Veciana, J. Adv. Mater. 1996, 8, 748. (b) Bonvoisin, J.; Launay, J.-P.; Van der Auweraer, M.; De Schryver, F. C. J. Phys. Chem. 1994, 98, 5052. (c) Ribou, A.-C.; Launay, J.-P.; Takahashi, K.; Nihira, T.; Tarutani, S.; Spangler, C. W. Inorg. Chem. 1994, 33, 1325. 


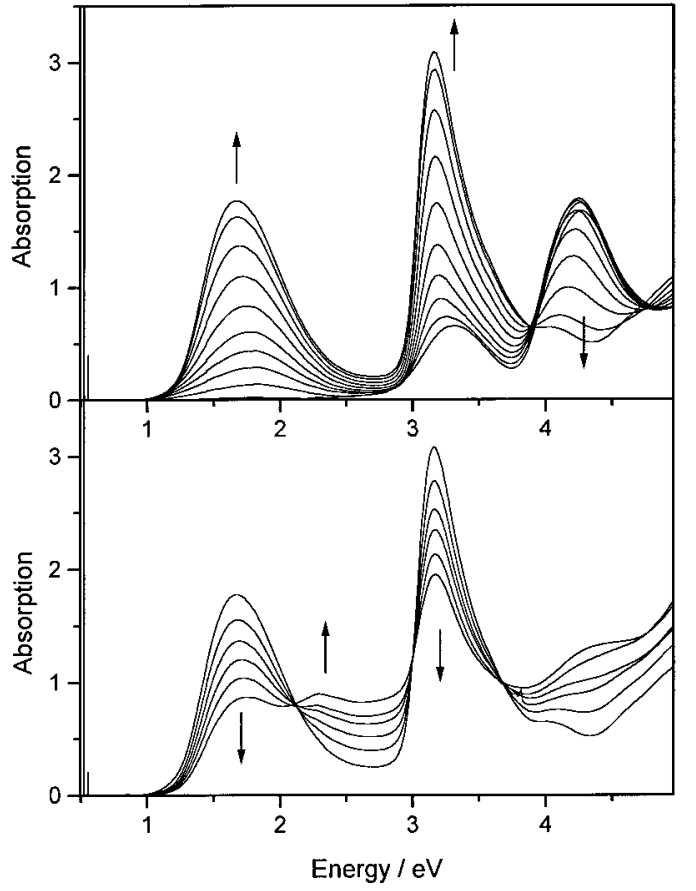

Figure 6. UV-vis-near IR spectra of the stepwise oxidation of 7 with PIFA in $\mathrm{CH}_{2} \mathrm{Cl}_{2} / \mathrm{TFA}(9: 1 \mathrm{v} / \mathrm{v})$ at $295 \mathrm{~K}$ : (top) oxidation of 7 to $\mathbf{7}^{\mathbf{*}+}$ to $\mathbf{7}^{\mathbf{2 \cdot 2}+}$; (bottom) oxidation from $\mathbf{7}^{\mathbf{2 \cdot 2}+}$ to $\mathbf{7}^{\mathbf{3 \cdot 3}+}$.

protonation results in quaternization of the amines, shortening the effective conjugation length. The new absorption around at $3.31 \mathrm{eV}$ is attributed to an intramolecular charge transfer. Oxidation with PIFA results in cation bands at 1.67 and 3.17 $\mathrm{eV}$ and an isosbestic point at $3.90 \mathrm{eV}$ (Figure 6). For 9, similar cation bands are found at 1.67 and $3.13 \mathrm{eV}$. The maximum absorbance is reached after addition of 2 and 3 equiv of oxidant for 7 and 9, respectively. Eventually, when more equivalents are added, the cation bands decrease and a new band at 2.31 $\mathrm{eV}$ (7) or $2.33 \mathrm{eV}(\mathbf{9})$ emerges which is attributed to doubly oxidized $p$-phenylenediamine units. During the oxidation process, no intervalence absorption bands were detected.

In addition to chemical oxidation, the intermediate oxidation states of the secondary amine oligomers $\mathbf{7}^{\mathbf{2 \cdot 2}+}$ and $\mathbf{9}^{\mathbf{3 \cdot 3}+}$ can also conveniently be obtained via "acid doping". When equimolar amounts of amine oligomer and corresponding imine oligomer are dissolved in acetonitrile, the UV-vis-near IR spectrum is a superposition of the absorptions of amine and imine, indicating that no reaction occurs. When $1 \%(\mathrm{v} / \mathrm{v})$ of TFA is added, the spectrum changes completely. The initial bands disappear and two new peaks emerge, identical to the absorptions of the intermediate oxidation state $\mathbf{7}^{\mathbf{2 \cdot 2}+}$ and $\mathbf{9}^{\mathbf{3 . 3}+}$ obtained in the oxidative doping experiment. The mechanism is a proton-triggered redox reaction between the amine and corresponding imine, similar to the acid doping process for the preparation of conducting polyaniline from the emeraldine base. In this process, the amine is oxidized to the intermediate oxidation state by the protonated imine, while at the same time the protonated imine is reduced to exactly the same species. The spectra of the neutral amine oligomers can be retrieved when an excess of hydrazine monohydrate is added to the sample. Since the overall process then is reduction of the imine oligomer, a double intensity of the amine oligomer absorption is found.

ESR Spectroscopy. When $<1$ equiv of $\mathrm{Thi}^{+} \mathrm{ClO}_{4}{ }^{-}$is added to a solution of $\mathbf{1}$ in dichloromethane, the ESR spectrum at room temperature reveals nine poorly resolved lines which arise from hyperfine interaction $\left(A_{\text {iso }}(\mathrm{N})=8 \mathrm{MHz}\right)$ with all four nitrogen

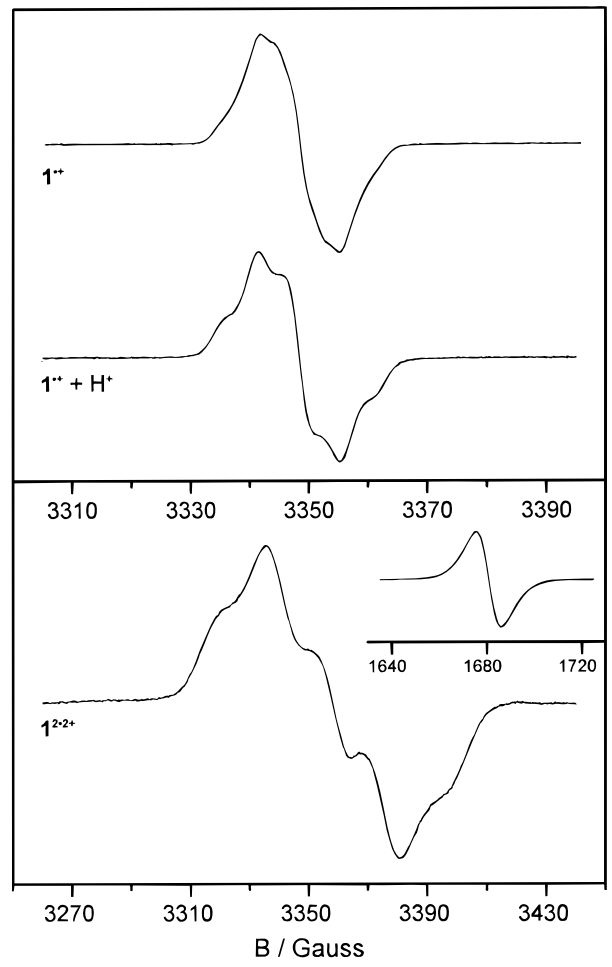

Figure 7. ESR spectra (top) of $\mathbf{1}^{++}$in $\mathrm{CH}_{2} \mathrm{Cl}_{2}$ recorded at room temperature; (middle) of $\mathbf{1}^{\circ+}$ in $\mathrm{CH}_{2} \mathrm{Cl}_{2} / \mathrm{TFA}(99: 1 \mathrm{v} / \mathrm{v})$ recorded at room temperature; (bottom) of $\mathbf{1}^{\mathbf{2} \mathbf{2}+}$ in $\mathrm{CH}_{2} \mathrm{Cl}_{2} / \mathrm{TFA}(99: 1 \mathrm{v} / \mathrm{v})$ recorded at $110 \mathrm{~K}$. The central line in the $\Delta M_{\mathrm{S}}= \pm 1$ spectrum is due to some doublet impurity.

nuclei in the molecule (Figure 7). This suggests a fast intramolecular charge transfer between the neutral and singly oxidized $p$-phenylenediamine moieties of $\mathbf{1}^{\bullet+}$. The charge transfer can be suppressed by lowering the temperature, as demonstrated by the anisotropic spectrum recorded in frozen solution. ${ }^{7}$ This spectrum (not shown) results from interaction with only two ${ }^{14} \mathrm{~N}$ nuclei and can be simulated with $A_{\|}(\mathrm{N})=$ $37 \mathrm{MHz}$ and $A_{\perp}(\mathrm{N})=5 \mathrm{MHz}$. Addition of acid also results in the localization of the unpaired electron in one of the $p$ phenylenediamine moieties, as evidenced by the five-line ESR spectrum with $A_{\text {iso }}(\mathrm{N})=16 \mathrm{MHz}$ recorded in the presence of TFA at room temperature (Figure 7). This effect can be explained by protonation of the unoxidized half of the molecule, making this unit a weaker electron donor. When the acidified sample is heated, the nine-line pattern reappears. Apparently, the charge transfer is a thermally activated process.

When 2 equiv of oxidant are added to $\mathbf{1}$, the lines in the room temperature spectrum broaden significantly, leaving just one featureless transition. This is due to the presence of triplet state diradicals, causing line broadening via efficient spin-spin relaxation.

The anisotropic spectrum of $\mathbf{1}$ oxidized with 2 equiv of $\mathrm{Thi}^{+} \mathrm{ClO}_{4}{ }^{-}$, recorded in dichloromethane containing some TFA at $110 \mathrm{~K}$, reveals the characteristic zero-field splitting associated with a high-spin state and a $\Delta M_{\mathrm{S}}= \pm 2$ transition at half-field (Figure 7). Without TFA, the spectrum reveals just one strong line at $g=2$ and no transition at half-field. In other solvents like chloroform, acetonitrile, and THF no additional acid is needed to bring about the zero-field splitting and half-field signal. These ESR signals are attributed to the di(cation radical) $\mathbf{1}^{\mathbf{2} \mathbf{2}+}$ in a triplet state. The zero-field parameters $(D=110$ $\mathrm{MHz} ; E \approx 0 \mathrm{MHz}$ ) have been determined by simulation of the $\Delta M_{\mathrm{S}}= \pm 1$ transitions of the ESR spectrum. Assuming a pointdipole approximation for the zero-field splitting, $D=110 \mathrm{MHz}$ corresponds to an average distance between the unpaired 


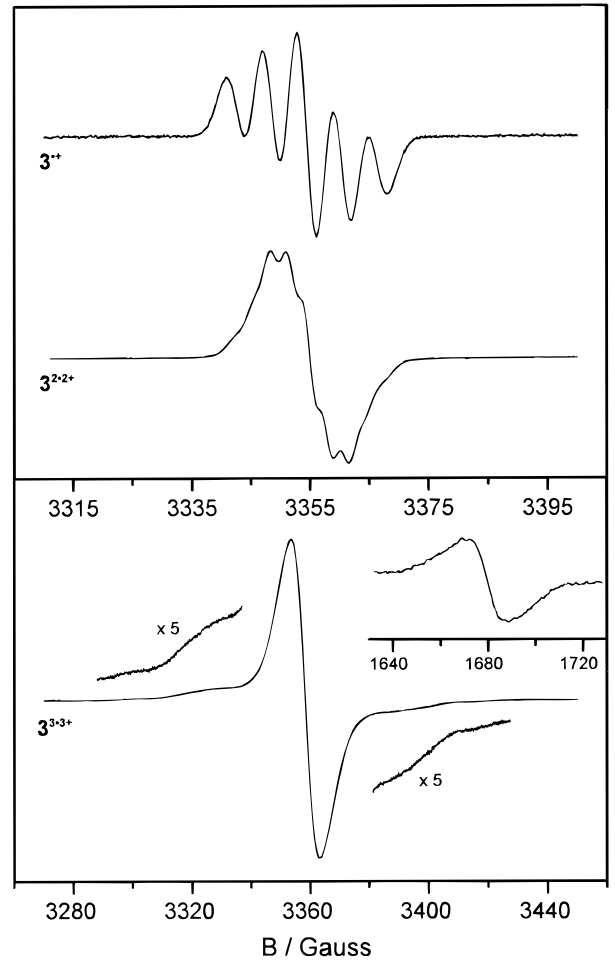

Figure 8. ESR spectra (top) of $\mathbf{3}^{-+}$in $\mathrm{CH}_{2} \mathrm{Cl}_{2}$ recorded at room temperature; (middle) of $\mathbf{3}^{\mathbf{2} 2+}$ in $\mathrm{CH}_{2} \mathrm{Cl}_{2}$ recorded at room temperature; (bottom) of $\mathbf{3}^{3 \cdot 3+}$ in $\mathrm{CH}_{2} \mathrm{Cl}_{2} / \mathrm{TFA}(99: 1 \mathrm{v} / \mathrm{v})$ recorded at $110 \mathrm{~K}$.

electrons of $8.7 \AA$. This is consistent with a separation of 9.8 $\AA$ between the centers of the $p$-phenylenediamine moieties, as estimated from standard bond lengths, assuming a planar geometry.

The ESR spectrum of $\mathbf{3}^{\boldsymbol{}}+$ is obtained after oxidation of $\mathbf{3}$ with $<1$ equiv of oxidant. The room temperature spectrum reveals a 1:2:3:2:1 five-line pattern $\left(A_{\mathrm{iso}}(\mathrm{N})=16 \mathrm{MHz}\right)$, irrespective of the presence of acid, resulting from interaction with only two nitrogen atoms (Figure 8). We propose that due to the inequivalence of the three $p$-phenylenediamine units, the singly oxidized hexaamine $3^{\bullet+}$ does not display intramolecular electron transfer, as observed for $\mathbf{1}^{\mathbf{+}}$. When more oxidant is added, the spectrum changes gradually into a nine-line pattern $\left(A_{\text {iso }}(\mathrm{N})=8 \mathrm{MHz}\right)$, which is reached just before 2 equiv are added (Figure 8 ). This pattern is caused by a diradical with a strong exchange interaction $(|J| \gg|A(\mathrm{~N})|)$, but weak dipolar spin-spin interaction between the unpaired electrons. Electrochemical studies indicated that in the di(cation radical) $\mathbf{3}^{\mathbf{2 \cdot 2}+}$ the charges and therefore also the unpaired electrons are localized within the two outer $p$-phenylenediamine units as a result of electrostatic repulsion. The long distance will reduce the dipolar spin-spin interaction. When the exchange interaction is large as compared to the hyperfine coupling $(|J| \gg$ $|A(\mathrm{~N})|)$, the ESR spectrum of the diradical will show a hyperfine pattern corresponding to twice the number of nuclei, with a coupling constant $A(\mathrm{~N}) / 2 .{ }^{19}$ Clearly, the experimental nine-line spectrum with $A_{\text {iso }}(\mathrm{N})=8 \mathrm{MHz}$ is in agreement with this prediction.

Oxidation beyond the dicationic state causes broadening of the room temperature spectrum due to the presence of a highspin species. In frozen solution, the anisotropic spectrum of the tri(cation radical) $\mathbf{3}^{\mathbf{3 0}+}$ is dominated by a strong transition at $g=2$ (Figure 8). Alongside of this line, broad shoulders

(19) (a) Luckhurst, G. R. Mol. Phys. 1966, 10, 543. (b) Luckhurst, G. R. In Spin Labeling Theory and Applications; Berliner, L. J., Ed.; Academic Press: New York, 1976; p 133.

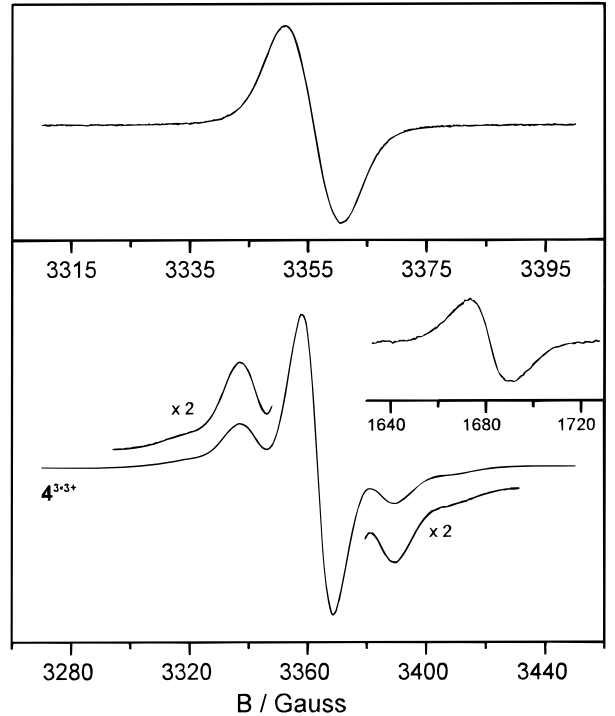

Figure 9. ESR spectra (top) of $\mathbf{4}$ oxidized to a minimum extend in $\mathrm{CH}_{2} \mathrm{Cl}_{2}$ recorded at room temperature; (bottom) of $4^{3 \cdot 3+}$ in $\mathrm{CH}_{2} \mathrm{Cl}_{2}$ / TFA $(99: 1 \mathrm{v} / \mathrm{v})$ recorded at $110 \mathrm{~K}$.

are observed that are attributed to the tri(cation radical) $\mathbf{3}^{\mathbf{3 . 3}+}$ in a quartet state and can be simulated using $D=77 \mathrm{MHz}$ and $E \approx 0 \mathrm{MHz}$ as zero-field parameters. According to the simulation, the quartet spectrum does not completely account for the intense central transition. The $\Delta M_{\mathrm{S}}= \pm 2$ transition of $\mathbf{3}^{\mathbf{3} \cdot 3+}$ is significantly broader than the half-field signal of the triplet state $\mathbf{1}^{\mathbf{2 \cdot 2}+}$. This is consistent with the expected zerofield splitting on the half-field signal of a quartet state. The actual $D$-splitting on the $\Delta M_{\mathrm{S}}= \pm 2$ transition, however, is obscured by the broad lines that result from hyperfine interaction with the nitrogen nuclei. A $\Delta M_{\mathrm{S}}= \pm 3$ transition could not be detected, not even at $4 \mathrm{~K}$. This can be rationalized by the theoretical ratio of the $\left|\Delta M_{\mathrm{S}}\right|=1,2$, and 3 transitions which is $1:\left(D / B_{0}\right)^{2}:\left(D / B_{0}\right)^{4} \cdot{ }^{20}$ Due to the relatively small $D$ value, the $\Delta M_{\mathrm{S}}= \pm 3$ transition signal is extremely weak and not detected.

In a dipolar approximation, the magnitude of $D$ is proportional to $1 / r^{3}$, where $r$ is the average distance between the unpaired electrons. For a triradical, the experimental $D$ will be the average of the interactions between each pair of electrons. If we assume the distance between the unpaired electrons in adjacent units of $\mathbf{3}^{\mathbf{3}+}$ to be similar to the distance in $\mathbf{1}^{\mathbf{2 \cdot 2}+}$, it is possible to make an estimate for $D\left(\mathbf{3}^{\mathbf{3 \cdot 3}+}\right) \approx\left[2 D\left(\mathbf{1}^{\mathbf{2 \cdot 2}+}\right)+\right.$ $\left.D\left(\mathbf{1}^{\mathbf{2} 2+}\right) / 8\right] / 3 \approx 78 \mathrm{MHz}$, in excellent agreement with the experimental value of $77 \mathrm{MHz}$.

In contrast with oligomers 1 and $\mathbf{3}$, oxidation of $\mathbf{4}$ immediately leads to one broad ESR transition at room temperature, even when much less than 1 equiv of oxidant is used (Figure 9). This behavior does not change when TFA is added. Apparently, high-spin species are generated at a very low oxidation level. This is confirmed by the spectra recorded at low temperature. After only 1 equiv of oxidant is added, the spectrum reveals the five-line pattern of a quartet state, which, apart from an increasing intensity, does not change upon addition of more oxidant up to 3 equiv (Figure 9). In the $g=4$ region, a very broad $\Delta M_{\mathrm{S}}= \pm 2$ transition is detected, but again no signals could be observed in the $\Delta M_{\mathrm{S}}= \pm 3$ region. We attribute these signals to the tri(cation radical) $\mathbf{4}^{\mathbf{3 \cdot 3}+}$ in a quartet state. The observation of the quartet tri(cation radical) at a low doping level can be explained by a disproportionation equilibrium that

(20) (a) Weissman, S. I.; Kothe, G. J. Am. Chem. Soc. 1975, 97, 2538 (b) Weissman, S. I. J. Am. Chem. Soc. 1975, 97, 2537. (c) Novak, C.; Kothe, G.; Zimmermann, H. Ber. Bunsen-Ges. Phys. Chem. 1974, 78, 265. (d) Müller, U.; Baumgarten, M. J. Am. Chem. Soc. 1995, 117, 5840. 


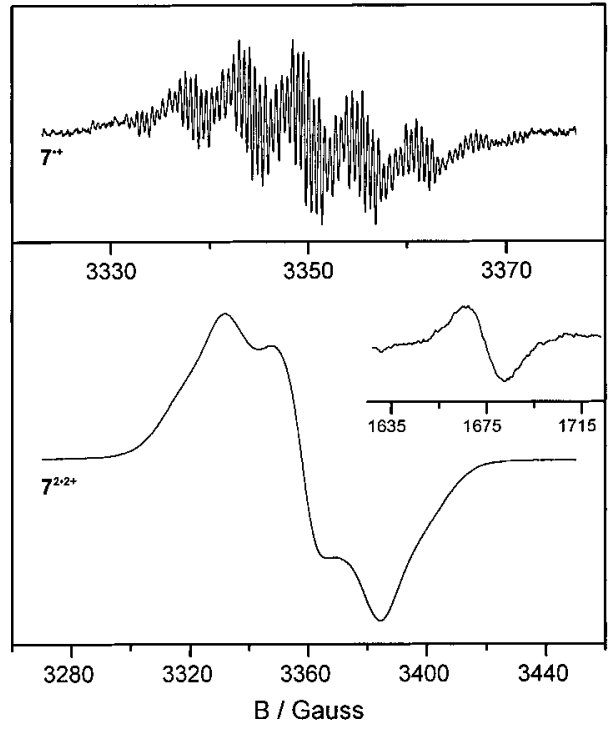

Figure 10. ESR spectra (top) of $\mathbf{7}^{++}$in $\mathrm{CH}_{2} \mathrm{Cl}_{2} / \mathrm{TFA}(9: 1 \mathrm{v} / \mathrm{v}$ ) recorded at room temperature; (bottom) of $\mathbf{7}^{\mathbf{2 \cdot 2}+}$ in $\mathrm{CH}_{2} \mathrm{Cl}_{2} / \mathrm{TFA}(9: 1 \mathrm{v} / \mathrm{v}$ ) recorded at $110 \mathrm{~K}$. The central line in the $\Delta M_{\mathrm{S}}= \pm 1$ spectrum is due to some doublet impurity.

favors the tri(cation radical) over the mono(cation radical). ${ }^{21}$ The early decrease of the intensity of the intervalence band in the optical spectra recorded during the stepwise oxidation of $\mathbf{4}$ is in agreement with this explanation. Spectral simulation of the $\Delta M_{\mathrm{S}}= \pm 1$ part of the ESR spectrum provides an estimate of the zero-field splitting parameters $D=68 \mathrm{MHz}$ and $E \approx 0$ $\mathrm{MHz}$, suggesting an average distance of $10.5 \AA$ between the unpaired electrons. The increased average distance for $\mathbf{4}^{\mathbf{3 . 3}+}$ as compared to $\mathbf{1}^{\mathbf{2 \cdot 2}+}$ and $\mathbf{3}^{\mathbf{3 \cdot 3}+}$ can be explained by the increased electrostatic repulsion resulting from the star-shaped topology of $\mathbf{4}^{\mathbf{3 0}+}$.

The ESR spectrum of $\mathbf{7}^{\bullet+}$ is obtained after doping of $\mathbf{7}$ with $<1$ equiv of PIFA in the presence of TFA and exhibits a wellresolved complex pattern, dominated by hyperfine interaction with two ${ }^{14} \mathrm{~N}$ nuclei and two amine protons (Figure 10). The isotropic couplings of $A_{\text {iso }}(\mathrm{N})=15 \mathrm{MHz}$ and $A_{\text {iso }}(\mathrm{H})=18 \mathrm{MHz}$ are in good agreement with values reported for the cation radical of DPBD. Interaction with only two nitrogen nuclei demonstrates that the unpaired electron is localized within half of the molecule and that no fast charge transfer occurs on the ESR time scale. The di(cation radical) $\mathbf{7}^{\mathbf{2} \mathbf{2}+}$ is most conveniently prepared from the 1:1 mixture of $\mathbf{7}$ and $\mathbf{8}$, by the "acid doping" process. The triplet ESR spectrum recorded at $110 \mathrm{~K}$ reveals zero-field splitting $(D=118 \mathrm{MHz} ; E \approx 0 \mathrm{MHz})$ and a $\Delta M_{\mathrm{S}}=$ \pm 2 transition at half-field.

For compound 9, a similar but less well-resolved roomtemperature ESR spectrum is recorded for a partially oxidized sample (Figure 11). If $>1$ equiv of oxidant is used, the anisotropic spectrum clearly displays zero-field splitting and gradually changes from a combination of doublet and triplet to a combination of triplet a quartet signals. Eventually, after the addition of 3 equiv, a five-line spectrum is obtained $(D=73$ $\mathrm{MHz} ; E \approx 0 \mathrm{MHz}$ ), as well as a broad $\Delta M_{\mathrm{S}}= \pm 2$ transition at half-field (Figure 11). These are attributed to $\mathbf{9}^{\mathbf{3 \cdot 3}+}$ in a quartet state. The "acid doping" of a 1:1 mixture of $\mathbf{9}$ and $\mathbf{1 0}$ affords identical ESR spectra.

Determination of the Ground States. Variable-temperature ESR experiments were carried out between 4 and $100 \mathrm{~K}$, in order to determine the ground states of the observed high-spin

(21) (a) Wolf, M. O.; Fox, H. H.; Fox, M. A. J. Org. Chem. 1996, 61, 287. (b) Grzeszczuk, M.; Smith, D. E. J. Electroanal. Chem. 1984, 162, 189.

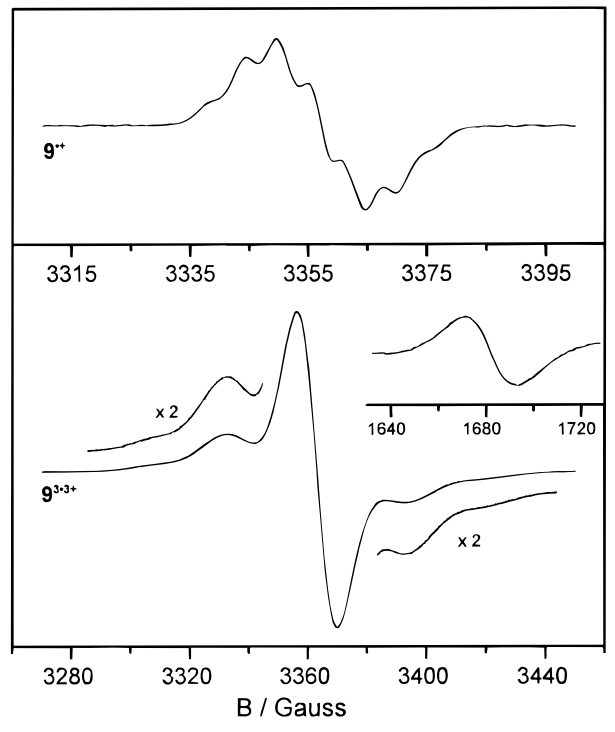

Figure 11. ESR spectra (top) of $\mathbf{9}^{\cdot+}$ in $\mathrm{CH}_{2} \mathrm{Cl}_{2} / \mathrm{TFA}$ recorded at room temperature; (bottom) of $\mathbf{9}^{\mathbf{3 \cdot 3}+}$ in $\mathrm{CH}_{2} \mathrm{Cl}_{2} / \mathrm{TFA}(99: 1 \mathrm{v} / \mathrm{v}$ ) recorded at $110 \mathrm{~K}$.

molecules. Meausurements for the triplet states of $\mathbf{1}^{\mathbf{2 \cdot 2}+}$ and $\mathbf{7}^{\mathbf{2} 2+}$ were performed on both the $\Delta M_{\mathrm{S}}= \pm 1$ and $\Delta M_{\mathrm{S}}= \pm 2$ transitions. For the quartet states the $\Delta M_{\mathrm{S}}= \pm 1$ transition was monitored for $4^{\mathbf{3 \cdot 3}+}$ and $\mathbf{9}^{\mathbf{3 \cdot 3}+}$, while the $\Delta M_{\mathrm{S}}= \pm 2$ line was considered for $3^{3 \cdot 3+}$. In the temperature range of $4-100 \mathrm{~K}$, the signal intensity of these transitions all follow Curie's law $(I=C / T)$. Apparently, no population or depopulation of the high-spin states occurs in this temperature region. This result can be interpreted in two ways. ${ }^{1 \mathrm{c}, 22}$ Either the high-spin state is the ground state and separated from other spin states by an energy gap greater than $R T$ at approximately $100 \mathrm{~K}$ or the ground state is unknown, but a very small energy gap (less than $R T$ at $4 \mathrm{~K}$ ) exists between the high-spin state and other spin states. In either case, the high-spin state corresponds to a lowenergy state.

\section{Synopsis}

One of the major challenges in the field of organic ferromagnets is the design and preparation of open-shell units that combine stability with the possibility to be incorporated in a chain or network proving the ferromagnetic interaction between the unpaired electrons. We have demonstrated that it is possible to apply the concepts used in the area of (semi)conducting polymers to prepare high-spin molecules with intramolecular ferromagnetic coupling. Taking advantage of the open-shell character of the charge carriers in conducting polyaniline, we have achieved ferromagnetic spin alignment in a series of oligomers, by simply changing the interconnection of the aniline units from an all-para to an alternating meta and para topology.

The precursor meta-para aniline oligomers are accessible via a series of copper-catalyzed Ullmann-type reactions. At room temperature, these compounds can be oxidized to the corresponding high-spin oligo(cation radical)s. The ferromagnetic spin-spin interaction between two adjacent singly oxidized $p$-phenylenediamine units is a consequence of the topology of the connecting $m$-phenylene rings. Delocalization of the unpaired electron within each $p$-phenylenediamine unit provides the desired chemical stability. Reversible oxidation has been achieved electrochemically or chemically, using $\mathrm{Thi}^{+} \mathrm{ClO}_{4}{ }^{-}$or PIFA in combination with TFA. In addition, we have shown

(22) (a) Iwamura, H.; Koga, N. Acc. Chem. Res. 1993, 26, 346. (b) Kanno, F.; Inoue, K.; Koga, N.; Iwamura, H. J. Phys. Chem. 1993, 97, 13267. (c) Ling, C.; Lahti, P. M. J. Am. Chem. Soc. 1994, 116, 8784. 
that acid doping is an efficient method to arrive at the required intermediate oxidation state of secondary meta-para aniline oligomers. ESR spectroscopy has provided insight into the spin distribution and the nature of the intramolecular spin-spin interaction of the various redox states of the meta-para aniline oligomers. High-spin states have been observed for all aniline oligomers in the intermediate oxidation state, despite the extended delocalization within the $p$-phenylenediamine units. Due to this delocalization, the zero-field splitting parameter $D$ is small compared to high-spin molecules with more localized unpaired electrons like carbenes and triarylmethyl radicals. ${ }^{23}$ We stress, however, that no direct relation exists between the zero-field splitting and the exchange energy $(|2 J|)$, which determines the actual energy gap between the high-spin and low-spin states. Variable-temperature ESR measurements on all high-spin meta-para aniline oligomers presented in this study reveal Curie behavior of the signal intensity between 4 and $100 \mathrm{~K}$. This indicates that the high-spin state is a lowenergy state, either corresponding to the ground state or as part of a (near) degeneracy with a low-spin state.

Summarizing, we have shown that polaronic triplet di(cation radical)s $\mathbf{1}^{\mathbf{2 \cdot 2}+}$ and $\mathbf{7}^{\mathbf{2} 2+}$ can be generated by oxidative or acid doping of neutral precursors. Moreover, we have demonstrated that these triplet di(cation radical) structures can successfully be extended to higher spin multiplicities in one and two dimensions. The chemical stability of the cationic oligoradicals and their intramolecular ferromagnetic spin-spin interaction confirm the feasibility of the concept of alternating meta and para aniline oligomers as building blocks for future polaronic ferromagnetic polymers.

\section{Experimental Section}

General Methods. Commercial grade reagents were used without further purification. Solvents were purified, dried, and degassed following standard procedures. Synthesis of 4-iodo- $N, N$-diphenylaniline, ${ }^{13} N, N^{\prime}, N^{\prime \prime}$-triphenyl-1,3,5-benzenetriamine, ${ }^{24}$ and $\mathbf{5}-\mathbf{8}^{11}$ have been reported previously. NMR spectra were recorded on a Bruker AM-400 spectrometer, chemical shifts are relative to TMS for ${ }^{1} \mathrm{H}$ and ${ }^{13} \mathrm{C}$ NMR spectra. Cyclic voltammograms were recorded with $0.1 \mathrm{M}$ tetrabutylammonium hexafluorophosphate as supporting electrolyte (unless stated otherwise) using a Potentioscan Wenking POS73 potentiostat. The working electrode was a platinum disc $\left(0.2 \mathrm{~cm}^{2}\right)$, the counterelectrode was a platinum plate $\left(0.5 \mathrm{~cm}^{2}\right)$, and the reference electrode was a saturated calomel electrode calibrated against a $\mathrm{Fc} /$ $\mathrm{Fc}^{+}$couple. The UV-vis-near IR spectra were recorded on a Perkin Elmer Lambda 900 spectrophotometer with a sealed $10 \mathrm{~mm}$ cuvette. ESR spectra were recorded on a Bruker ER 200D spectrometer, operating with an X-band standard or TMH cavity, interfaced to a Bruker Aspect 3000 data system. Temperature was controlled by a Bruker ER4111 variable-temperature unit between 100 and $370 \mathrm{~K}$ or by an Oxford 3120 temperature controller combined with an ESR 900 continuous flow cryostat in the range of $4-100 \mathrm{~K}$. Saturation of the ESR signal during variable-temperature experiments was avoided by using low microwave powers, i.e., $200 \mathrm{nW}$ for the $\Delta M_{\mathrm{S}}= \pm 1$ transition and $1 \mathrm{~mW}$ for the $\Delta M_{\mathrm{S}}= \pm 2$ transition, which is well within the range where signal intensity is proportional to the square root of the microwave power at $4 \mathrm{~K}$. For intensity measurements, the spectra were base line corrected. Powder ESR spectrum simulations were carried out with a spin Hamiltonian incorporating the electron Zeeman term and the dipolar spin-spin coupling. The $g$ value was assumed to be isotropic. Unresolved hyperfine couplings were generally treated using different Gaussian line widths for the three principal directions.

$N, N^{\prime}$-Bis[4-(diphenylamino)phenyl]- $N, N^{\prime}$-diphenyl-1,3-benzenediamine (1). $n$-Butyllithium (1.0 mL 1.6 M in hexane, $1.6 \mathrm{mmol})$ was

(23) (a) Wasserman, E.; Murray, R. W.; Yager, W. A.; Trozzolo, A. M.; Smolinsky, G. J. Am. Chem. Soc. 1967, 89, 5076. (b) Itoh, K. Chem. Phys. Lett. 1967, 1, 235. (c) Luckhurst, G. R.; Pedulli, G. F.; Tiecco, M. J. Chem. Soc. (B) 1971, 329.

(24) Buu-Hoï, Ng. Ph. J. Chem. Soc. 1952, 4346. slowly added to a solution of $N, N^{\prime}$-diphenyl-1,3-benzenediamine $(0.18$ $\mathrm{g}, 0.7 \mathrm{mmol})$ in diphenyl ether $(15 \mathrm{~mL})$ at room temperature. After $15 \mathrm{~min}$ of stirring, 4-iodo- $N, N$-diphenylaniline $(0.52 \mathrm{~g}, 1.4 \mathrm{mmol})$ and copper(I) iodide (13 mg, $0.07 \mathrm{mmol}$ ) were added, and the mixture was heated to $200{ }^{\circ} \mathrm{C}$ for $48 \mathrm{~h}$. After cooling, ethyl acetate $(50 \mathrm{~mL})$ was added and the reaction mixture was filtered over hyflo, washed with a saturated aqueous solution of ammonium chloride, and dried over magnesium sulfate. Evaporation of the solvent, flash column chromatography $\left(\mathrm{SiO}_{2}\right.$, hexane/ $\mathrm{CHCl}_{3} 3: 1$ to 2:1) and recrystallization from benzene afforded pure $1(0.32 \mathrm{~g}, 61 \%)$ as white crystals: $\mathrm{mp} 216-$ $218{ }^{\circ} \mathrm{C} ;{ }^{1} \mathrm{H} \mathrm{NMR}\left(\mathrm{CDCl}_{3}\right) \delta 6.68\left(2 \mathrm{H}, \mathrm{dd}, J=8.0\right.$ and $\left.2.0 \mathrm{~Hz}, \mathrm{H}_{\mathrm{A}}-4\right)$, $6.86\left(1 \mathrm{H}, \mathrm{t}, J=2.0 \mathrm{~Hz}, \mathrm{H}_{\mathrm{A}}-2\right), 6.94-7.01\left(14 \mathrm{H}, \mathrm{m}, \mathrm{H}_{\mathrm{B}}-4, \mathrm{H}_{\mathrm{C}}-2, \mathrm{H}_{\mathrm{C}}-3\right.$, $\left.\mathrm{H}_{\mathrm{D}}-4\right), 7.06-7.12\left(13 \mathrm{H}, \mathrm{m}, \mathrm{H}_{\mathrm{A}}-5, \mathrm{H}_{\mathrm{B}}-2, \mathrm{H}_{\mathrm{D}}-2\right), 7.19\left(12 \mathrm{H}, \mathrm{m}, \mathrm{H}_{\mathrm{B}}-3\right.$, $\left.\mathrm{H}_{\mathrm{D}}-3\right) ;{ }^{13} \mathrm{C} \mathrm{NMR}\left(\mathrm{CDCl}_{3}\right) \delta 117.43\left(\mathrm{C}_{\mathrm{A}}-4\right), 118.57\left(\mathrm{C}_{\mathrm{A}}-2\right), 122.40\left(\mathrm{C}_{\mathrm{B}^{-}}\right.$ $\left.4, C_{D}-4\right), 123.69\left(C_{B}-2\right), 123.77\left(C_{D}-2\right), 125.33\left(C_{C}-3\right), 125.56\left(C_{C}-2\right)$, $129.08\left(\mathrm{C}_{\mathrm{B}}-3\right), 129.17\left(\mathrm{C}_{\mathrm{D}}-3\right), 129.65\left(\mathrm{C}_{\mathrm{A}}-5\right), 142.58\left(\mathrm{C}_{\mathrm{C}}-1\right), 142.96$ $\left(\mathrm{C}_{\mathrm{C}}-4\right), 147.57\left(\mathrm{C}_{\mathrm{B}}-1\right), 147.87\left(\mathrm{C}_{\mathrm{D}}-1\right), 148.60\left(\mathrm{C}_{\mathrm{A}}-1\right)$. Anal Calcd for $\mathrm{C}_{54} \mathrm{H}_{42} \mathrm{~N}_{4}$ : C, 86.83; H, 5.67; N, 7.50. Found: C, 86.76; H, 5.78; N, 7.66. ES-MS $\mathrm{m} / \mathrm{z}\left(\mathrm{M}^{+}\right)$calcd 746.3, obsd 746.3.

$N$-[4-(Diphenylamino)phenyl]- $N, N^{\prime}$-diphenyl-1,3-benzenediamine (2). In a procedure similar to the synthesis of $\mathbf{1}, N, N^{\prime}$-diphenyl1,3-benzenediamine ( $0.78 \mathrm{~g}, 3 \mathrm{mmol})$ was reacted with $n$-BuLi, 4-iodo$\mathrm{N}, \mathrm{N}$-diphenylaniline $(1.11 \mathrm{~g}, 3 \mathrm{mmol})$, and copper(I) iodide $(0.04 \mathrm{~g}$, $0.2 \mathrm{mmol})$. Flash column chromatography $\left(\mathrm{SiO}_{2}\right.$, hexane/ $\mathrm{CHCl}_{3} 3: 1$ to 2:1) afforded $\mathbf{1}(0.29 \mathrm{~g}, 13 \%)$ and $2(0.65 \mathrm{~g}, 43 \%)$ as a gray solid: $\mathrm{mp} 178{ }^{\circ} \mathrm{C} ;{ }^{1} \mathrm{H}$ NMR $\left(\mathrm{CDCl}_{3}\right) \delta 5.6(1 \mathrm{H}, \mathrm{bs}, \mathrm{NH}), 6.63\left(1 \mathrm{H}, \mathrm{m}, \mathrm{H}_{\mathrm{A}}-6\right)$, $6.66\left(1 \mathrm{H}, \mathrm{m}, \mathrm{H}_{\mathrm{A}}-4\right), 6.77\left(1 \mathrm{H}, \mathrm{t}, J=2.1 \mathrm{~Hz}, \mathrm{H}_{\mathrm{A}}-2\right), 6.89(1 \mathrm{H}, \mathrm{tt}, J=$ 7.3 and $\left.1.1 \mathrm{~Hz}, \mathrm{H}_{\mathrm{B}^{\prime}}-4\right), 6.9-7.0\left(9 \mathrm{H}, \mathrm{m}, \mathrm{H}_{\mathrm{B}^{\prime}}-2, \mathrm{H}_{\mathrm{C}^{-}}-2, \mathrm{H}_{\mathrm{C}^{-}}-3, \mathrm{H}_{\mathrm{B}}-4, \mathrm{H}_{\mathrm{D}^{-}}\right.$ 4), 7.05-7.15 (7H, m, $\left.\mathrm{H}_{\mathrm{A}}-5, \mathrm{H}_{\mathrm{B}}-2, \mathrm{H}_{\mathrm{D}}-2\right), 7.15-7.25\left(8 \mathrm{H}, \mathrm{m}, \mathrm{H}_{\mathrm{B}}-3\right.$, $\left.\mathrm{H}_{\mathrm{D}}-3, \mathrm{H}_{\mathrm{B}^{\prime}}-3\right) ;{ }^{13} \mathrm{C} \mathrm{NMR}\left(\mathrm{CDCl}_{3}\right) \delta 111.58\left(\mathrm{C}_{\mathrm{A}}-4\right), 112.67\left(\mathrm{C}_{\mathrm{A}}-2\right), 116.00$ $\left(\mathrm{C}_{\mathrm{A}}-6\right), 117.61\left(\mathrm{C}_{\mathrm{B}^{\prime}}-2\right), 120.82\left(\mathrm{C}_{\mathrm{B}^{\prime}}-4\right), 122.36\left(\mathrm{C}_{\mathrm{D}}-4\right), 122.52\left(\mathrm{C}_{\mathrm{B}}-4\right)$, $123.69\left(\mathrm{C}_{\mathrm{D}}-2\right), 124.03\left(\mathrm{C}_{\mathrm{B}}-2\right), 125.42\left(\mathrm{C}_{\mathrm{C}}-3\right), 125.63\left(\mathrm{C}_{\mathrm{C}}-2\right), 129.15$ $\left(\mathrm{C}_{\mathrm{B}}-3, \mathrm{C}_{\mathrm{D}^{-}}-3\right), 129.22\left(\mathrm{C}_{\mathrm{B}^{\prime}}-3\right), 129.84\left(\mathrm{C}_{\mathrm{A}^{-}}-5\right), 142.73,142.82,142.89$, $143.78\left(\mathrm{C}_{\mathrm{A}^{-}}-3, \mathrm{C}_{\mathrm{B}^{\prime}}-1, \mathrm{C}_{\mathrm{C}^{-}}-1, \mathrm{C}_{\mathrm{C}^{-}}-4\right), 147.66\left(\mathrm{C}_{\mathrm{B}}-1\right), 147.82\left(\mathrm{C}_{\mathrm{D}}-1\right), 148.96$ $\left(\mathrm{C}_{\mathrm{A}}-1\right)$.

$N, N^{\prime}-\operatorname{Bis}\{3-[N$-(diphenylamino)phenyl- $N$-phenylamino $]$ phenyl $\}$ $\boldsymbol{N}, \boldsymbol{N}^{\prime}$-diphenyl-1,4-benzenediamine (3). To a solution of $2(0.46 \mathrm{~g}$, $1.1 \mathrm{mmol})$ in diphenyl ether $(10 \mathrm{~mL})$ were added sodium hydride $(0.05$ $\mathrm{g}, 2 \mathrm{mmol}), 1,4$-diiodobenzene ( $0.17 \mathrm{~g}, 0.5 \mathrm{mmol})$, and copper(I) iodide (20 mg, $0.1 \mathrm{mmol}$ ), and the mixture was heated to $200^{\circ} \mathrm{C}$ for $48 \mathrm{~h}$. After cooling, ethyl acetate $(50 \mathrm{~mL})$ was added and the reaction mixture was filtered over hyflo, washed with a saturated aqueous solution of ammonium chloride, and dried over magnesium sulfate. Evaporation of the solvent and flash column chromatography $\left(\mathrm{SiO}_{2}\right.$, hexane $/ \mathrm{CHCl}_{3}$ $3: 1$ to $2: 1)$ afforded $3(0.28 \mathrm{~g}, 51 \%)$ as a light gray solid: $\mathrm{mp} 234{ }^{\circ} \mathrm{C}$; ${ }^{1} \mathrm{H}$ NMR $\left(\mathrm{CDCl}_{3}\right) \delta 6.61\left(2 \mathrm{H}, \mathrm{dd}, J=8.0\right.$ and $\left.2.1 \mathrm{~Hz}, \mathrm{H}_{\mathrm{C}}-6\right), 6.65$ $\left(2 \mathrm{H}, \mathrm{dd}, J=8.0\right.$ and $\left.2.1 \mathrm{~Hz}, \mathrm{H}_{\mathrm{C}}-4\right), 6.85\left(2 \mathrm{H}, \mathrm{t}, J=2.1 \mathrm{~Hz}, \mathrm{H}_{\mathrm{C}}-2\right)$, 6.9-7.0 (20H, m, $\left.\mathrm{H}_{\mathrm{A}}, \mathrm{H}_{\mathrm{B}}-4, \mathrm{H}_{\mathrm{D}}-4, \mathrm{H}_{\mathrm{E}}-2, \mathrm{H}_{\mathrm{E}}-3, \mathrm{H}_{\mathrm{F}}-4\right), 7.05-7.08(18 \mathrm{H}$, $\left.\mathrm{m}, \mathrm{H}_{\mathrm{B}}-2, \mathrm{H}_{\mathrm{C}}-5, \mathrm{H}_{\mathrm{D}}-2, \mathrm{H}_{\mathrm{F}}-2\right), 7.15-7.25\left(16 \mathrm{H}, \mathrm{m}, \mathrm{H}_{\mathrm{B}}-3, \mathrm{H}_{\mathrm{D}}-3, \mathrm{H}_{\mathrm{F}}-3\right)$; ${ }^{13} \mathrm{C}$ NMR $\left(\mathrm{CDCl}_{3}\right) \delta 117.41\left(\mathrm{C}_{\mathrm{C}-}-4, \mathrm{C}_{\mathrm{C}}-6\right), 118.53\left(\mathrm{C}_{\mathrm{C}}-2\right), 122.36,122.37$ $\left(\mathrm{C}_{\mathrm{B}}-4, \mathrm{C}_{\mathrm{D}}-4\right), 122.39\left(\mathrm{C}_{\mathrm{F}}-4\right), 123.65,123.68\left(\mathrm{C}_{\mathrm{B}}-2, \mathrm{C}_{\mathrm{D}}-2\right), 123.76\left(\mathrm{C}_{\mathrm{F}}-\right.$ 2), $125.32\left(\mathrm{C}_{\mathrm{E}}-3\right), 125.51,125.54\left(\mathrm{C}_{\mathrm{A}}-2, \mathrm{C}_{\mathrm{E}}-2\right), 129.07\left(\mathrm{C}_{\mathrm{B}}-3, \mathrm{C}_{\mathrm{D}}-3\right)$, $129.14\left(\mathrm{C}_{\mathrm{F}}-3\right), 129.67\left(\mathrm{C}_{\mathrm{C}}-5\right), 142.57,142.62\left(\mathrm{C}_{\mathrm{A}^{-}}-1, \mathrm{C}_{\mathrm{E}^{-}}-1\right), 142.91\left(\mathrm{C}_{\mathrm{E}^{-}}\right.$ 4) $147.52,147.54\left(\mathrm{C}_{\mathrm{B}}-1, \mathrm{C}_{\mathrm{D}}-1\right), 147.85\left(\mathrm{C}_{\mathrm{F}}-1\right), 148.54,148.57\left(\mathrm{C}_{\mathrm{C}}-1\right.$, $\left.\mathrm{C}_{\mathrm{C}^{-}} 3\right)$. ES-MS $m / z\left(\mathrm{M}^{+}\right)$calcd for $\mathrm{C}_{78} \mathrm{H}_{60} \mathrm{~N}_{6} 1080.5$, obsd 1080.5 .

$N, N^{\prime}, N^{\prime \prime}$-Tris[4-(diphenylamino)phenyl]- $N, N^{\prime}, N^{\prime \prime}$-triphenyl-1,3,5benzenetriamine (4). To a solution of $N, N^{\prime}, N^{\prime \prime}$-triphenyl-1,3,5benzenetriamine $(0.74 \mathrm{~g}, 2.0 \mathrm{mmol})$ in diphenyl ether $(25 \mathrm{~mL})$ were added sodium hydride $(0.25 \mathrm{~g}, 10 \mathrm{mmol})$, 4-iodo- $N, N$-diphenylaniline (2.71 g, $7.3 \mathrm{mmol})$, and copper(I) iodide ( $0.12 \mathrm{~g}, 0.6 \mathrm{mmol})$, and the mixture was heated to $200{ }^{\circ} \mathrm{C}$ for $48 \mathrm{~h}$. After cooling, ethyl acetate $(50 \mathrm{~mL})$ was added and the reaction mixture was filtered over hyflo, washed with a saturated aqueous solution of ammonium chloride, and dried over magnesium sulfate. Evaporation of the solvent and flash column chromatography $\left(\mathrm{SiO}_{2}\right.$, hexane/ $\mathrm{CHCl}_{3} 3: 1$ to 2:1) afforded pure $4(0.80 \mathrm{~g}, 37 \%): \operatorname{mp~} 239{ }^{\circ} \mathrm{C} ;{ }^{1} \mathrm{H}$ NMR $\left(330 \mathrm{~K}, \mathrm{CDCl}_{3}\right) \delta 6.36(3 \mathrm{H}$, bs, $\left.\mathrm{H}_{\mathrm{A}}\right), 6.8-6.94\left(21 \mathrm{H}, \mathrm{m}, \mathrm{H}_{\mathrm{B}}-4, \mathrm{H}_{\mathrm{C}}-2, \mathrm{H}_{\mathrm{C}}-3, \mathrm{H}_{\mathrm{D}}-4\right), 6.95-7.05(18 \mathrm{H}$, $\left.\mathrm{m}, \mathrm{H}_{\mathrm{B}}-2, \mathrm{H}_{\mathrm{D}}-2\right), 7.13\left(6 \mathrm{H}, \mathrm{t}, J=7.5 \mathrm{~Hz}, \mathrm{H}_{\mathrm{B}}-3\right), 7.17(12 \mathrm{H}, \mathrm{t}, J=7.5$ $\left.\mathrm{Hz}, \mathrm{H}_{\mathrm{D}}-3\right) ;{ }^{13} \mathrm{C}$ NMR $\left(330 \mathrm{~K}, \mathrm{CDCl}_{3}\right) \delta 112.79\left(\mathrm{C}_{\mathrm{A}}-2\right), 122.48\left(\mathrm{C}_{\mathrm{B}}-4\right)$, $122.51\left(\mathrm{C}_{\mathrm{D}}-4\right), 123.85\left(\mathrm{C}_{\mathrm{B}}-2\right), 123.93\left(\mathrm{C}_{\mathrm{D}}-2\right), 125.34\left(\mathrm{C}_{\mathrm{C}}-3\right), 125.69$ $\left(\mathrm{C}_{\mathrm{C}}-2\right), 129.00\left(\mathrm{C}_{\mathrm{B}}-3\right), 129.19\left(\mathrm{C}_{\mathrm{D}}-3\right), 142.64\left(\mathrm{C}_{\mathrm{C}}-1\right), 143.24\left(\mathrm{C}_{\mathrm{C}}-4\right)$, 
$147.56\left(\mathrm{C}_{\mathrm{B}}-1\right), 148.09\left(\mathrm{C}_{\mathrm{D}}-1\right), 149.28\left(\mathrm{C}_{\mathrm{A}}-1\right)$; ES-MS $m / z\left(\mathrm{M}^{+}\right)$calcd for $\mathrm{C}_{78} \mathrm{H}_{60} \mathrm{~N}_{6} 1080.5$, obsd 1080.5 .

$N, N^{\prime}, N^{\prime \prime}$-Tris[4-(phenylamino)phenyl]-1,3,5-benzenetriamine (9). A mixture of phloroglucinol $(0.25 \mathrm{~g}, 2 \mathrm{mmol}), N$-phenyl-1,4-benzenediamine $(1.47 \mathrm{~g}, 8 \mathrm{mmol})$, and iodine $(0.03 \mathrm{~g}, 0.12 \mathrm{mmol})$ was stirred at $180^{\circ} \mathrm{C}$ for $6 \mathrm{~h}$. The water formed during the reaction was removed from the mixture by careful evacuation of the reaction vessel. After cooling, the solid product was suspended in $\mathrm{MeOH} / \mathrm{CHCl}_{3}$ using an ultrasonic bath. The gray solid was filtered, washed thoroughly with $\mathrm{CHCl}_{3}$, and recrystallized from acetonitrile to give pure $9(0.98 \mathrm{~g}, 78 \%)$ as a white crystalline solid: $\mathrm{mp} 210{ }^{\circ} \mathrm{C} ;{ }^{1} \mathrm{H}$ NMR (acetone- $d_{6}$ ) $\delta 6.27$ $\left(3 \mathrm{H}, \mathrm{s}, \mathrm{H}_{\mathrm{A}}\right), 6.74\left(3 \mathrm{H}, \mathrm{tt}, J=7.3\right.$ and $\left.1.1 \mathrm{~Hz}, \mathrm{H}_{\mathrm{C}}-4\right), 6.99(6 \mathrm{H}, \mathrm{dd}, J$ $=7.5$ and $\left.1.2 \mathrm{~Hz}, \mathrm{H}_{\mathrm{C}}-2\right), 6.99(3 \mathrm{H}, \mathrm{s}, \mathrm{NH}), 7.08(6 \mathrm{H}, \mathrm{d}, J=9.0 \mathrm{~Hz}$, $\left.\mathrm{H}_{\mathrm{B}}-2\right), 7.10(3 \mathrm{H}, \mathrm{s}, \mathrm{NH}), 7.12\left(6 \mathrm{H}, \mathrm{d}, J=9.0 \mathrm{~Hz}, \mathrm{H}_{\mathrm{B}}-3\right), 7.16(6 \mathrm{H}, \mathrm{dd}$, 7.5 and $\left.7.3 \mathrm{~Hz}, \mathrm{H}_{\mathrm{C}}-3\right) ;{ }^{13} \mathrm{C}$ NMR (acetone- $\left.d_{6}\right) \delta 96.3\left(\mathrm{C}_{\mathrm{A}}-2\right), 116.3$ $\left(\mathrm{C}_{\mathrm{C}^{-}}-2\right), 119.6\left(\mathrm{C}_{\mathrm{C}^{-}}-4\right), 121.2,121.3\left(\mathrm{C}_{\mathrm{B}}-2, \mathrm{C}_{\mathrm{B}}-3\right), 130.0\left(\mathrm{C}_{\mathrm{C}^{-}}-3\right), 137.5$, $138.7\left(\mathrm{C}_{\mathrm{B}}-1, \mathrm{C}_{\mathrm{B}}-4\right), 144.3\left(\mathrm{C}_{\mathrm{C}^{-}}-1\right), 147.6\left(\mathrm{C}_{\mathrm{A}}-1\right)$; ES-MS $m / z\left(\mathrm{M}^{+}\right)$calcd 624.3, obsd 624.5.

$N, N^{\prime}, N^{\prime \prime}$-Tris-[4-(phenylimino)-cyclohexa-2,5-dienylidene]-1,3,5benzenetriamine (10). To hexaamine $9(110 \mathrm{mg}, 0.025 \mathrm{mmol})$ in dioxane $(5 \mathrm{~mL})$ was added $\mathrm{PbO}_{2}(0.6 \mathrm{~g}, 2.5 \mathrm{mmol})$. The mixture was stirred at room temperature for $30 \mathrm{~min}$. The dark red solution was filtered over silica, and the solvent was removed by evaporation. The product $(98 \mathrm{mg}, 90 \%)$ was isolated as a mixture of four cis-trans isomers $(\mathbf{1 0 a}-\mathbf{d})$. These isomers could not be separated by column chromatography since isomerization takes place during this process: ${ }^{1} \mathrm{H} \mathrm{NMR}\left(\mathrm{CDCl}_{3}\right) \delta 6.17,6.20,6.24,6.27((0.12+0.34+0.39+$ $\left.0.15) 3 \mathrm{H}, 4 \mathrm{~s}, \mathrm{H}_{\mathrm{A}}-2 \mathbf{a}-\mathbf{d}\right), 6.75-7.10\left(18 \mathrm{H}, \mathrm{m}, \mathrm{H}_{\mathrm{B}}-2, \mathrm{H}_{\mathrm{B}}-3, \mathrm{H}_{\mathrm{B}}-5, \mathrm{H}_{\mathrm{B}}-\right.$ $\left.6, \mathrm{H}_{\mathrm{C}}-2\right), 7.17\left(3 \mathrm{H}, \mathrm{m}, \mathrm{H}_{\mathrm{C}}-4\right), 7.33-7.41\left(6 \mathrm{H}, \mathrm{m}, \mathrm{H}_{\mathrm{C}}-3\right) ;{ }^{13} \mathrm{C} \mathrm{NMR}$ $\left(\mathrm{CDCl}_{3}\right) \delta 108.72,108.80\left(\mathrm{C}_{\mathrm{A}}-2, \mathrm{C}_{\mathrm{A}}-4, \mathrm{C}_{\mathrm{A}}-6\right), 120.49,120.56\left(\mathrm{C}_{\mathrm{C}}-2\right)$, $124.34,124.39,124.44,124.88,124.98,124.01,125.05,125.59\left(\operatorname{syn}\left(\mathrm{C}_{\mathrm{B}^{-}}\right.\right.$ $\left.\left.2, \mathrm{C}_{\mathrm{B}}-3, \mathrm{C}_{\mathrm{B}}-5, \mathrm{C}_{\mathrm{B}}-6\right)\right), 125.27,125.32\left(\mathrm{C}_{\mathrm{C}^{-}} 4\right), 128.92,128.94\left(\mathrm{C}_{\mathrm{C}^{-}}-3\right)$, $136.05,136.07,136.11,137.00,137.21,137.24,137.28,138.24$ $\left(\operatorname{anti}\left(\mathrm{C}_{\mathrm{B}}-2, \mathrm{C}_{\mathrm{B}}-3, \mathrm{C}_{\mathrm{B}}-5, \mathrm{C}_{\mathrm{B}}-6\right)\right), 149.86\left(\mathrm{C}_{\mathrm{C}}-1\right), 151.38,151.41,151.45$, 151.46, 151.51 $\left(\mathrm{C}_{\mathrm{A}}-1, \mathrm{C}_{\mathrm{A}}-3, \mathrm{C}_{\mathrm{A}}-5\right), 158.06,158.08,158.11,158.14$, 158.16, $158.19\left(\mathrm{C}_{\mathrm{B}}-1\right), 158.92,158.97\left(\mathrm{C}_{\mathrm{B}}-4\right)$; ES-MS $m / z\left(\mathrm{M}+\mathrm{H}^{+}\right)$ calcd 619.3, obsd 619.3.

Acknowledgment. We thank Professor E. W. Meijer, Dr. J. A. J. M. Vekemans, and Dr. E. E. Havinga for helpful discussions and comments.

JA963772X 